
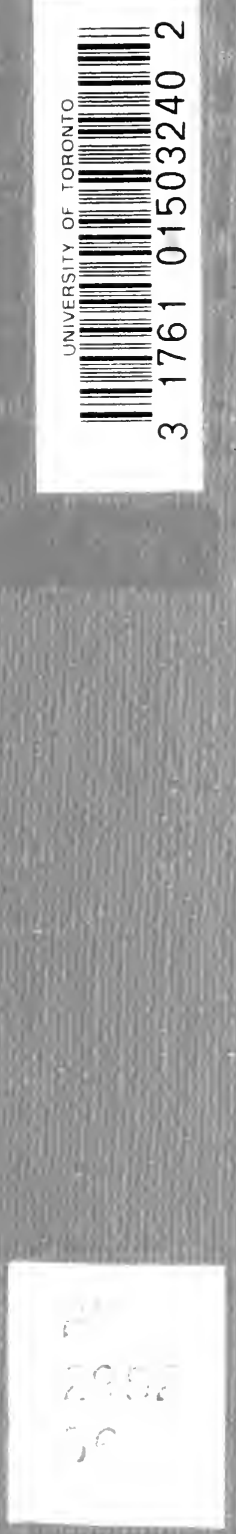





$912^{\circ}$ 



\section{AN ESSAY ON SHAKESPEARE'S RELATION TO TRADITION}


NEw YoRK :

LONGMANS, GREEN AND CO., FOURTH AVENUE AND THIRTIETH STREET 


\section{An}

\section{Essay on Shakespeare's}

\section{Relation to Tradition}

BY

JANET SPENS, D.LitT.

RESIDENT ENGLISH TUTOR AT LADY MARGARET HALL

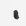

\section{OXFORD}

B. H. BLACKWELL BROAD STREET MCMXVI 


$$
\begin{aligned}
& \text { PR } \\
& 2952 \\
& 56
\end{aligned}
$$

ELECTRONIC VERSION

AVAILABLE

No. 00000223 


\section{PROFESSOR A. C. BRADLEY}

FROM ONE OF HIS STUDENTS 



\section{PREFACE}

THIs short study was first suggested by lectures given by Professor Gilbert Murray, on "The Ritual Forms preserved in Greek Tragedy." Later on, by the time it took its first shape in three lectures on "The Scapegoat in Greek and English Drama," an older suggestion of his about the feeling of ãyos in CEdipus had become connected with it. I should explain, however, that the study was not seen by him in its present form, and it may therefore contain statements-or at least emphasis on statements-with which he would not agree.

J. S.

OXFORD,

June, 1916. 



\section{CONTEN'TS}

I

COMEDY

SECTION

I. TYPES OF COMEDY BEFORE SHAKESPEARE -

II. EVIDENCE OF THE INFLUENCE OF MUNDAY

ON SHAKESPEARE LEADING UP TO SHAKE-

SPEARE'S USE OF THE FOLK-PLAY

- 16

III. THE TRACES OF FOLK-PLAYS IN SHAKESPEARE'S DRAMA

TRAGEDY AND CONCLUSION

I. THE GREEK TRAGIC HERO



II. THE PRE-SHAKESPEAREAN AND SHAKESPEAREAN TRAGIC HERO TO THE EARLIEST HAMLET. HONOUR THE SUBJECT OF ELIZABETHAN TRAGEDY. SHAKESPEARE'S REJECTION OF THE SUPERMAN . - 
III. A DIGRESSION TO SUGGEST THE WAY IN WHICH POST-SHAKESPEAREAN TRAGEDY IS STILL OCCUPIED WITH THE SAME CONCEPTION IN A NARROWER FORM -

IV. THE LATER HAMLET AND KING LEAR -

v. CONCLUSION : THE INDIVIDUAL IS ESSENTIALLY TRAGIC; CONSOLATION IS ONLY POSSIBLE WHEN WE REGARD ALL LIFE AS ONE 101 


\section{AN ESSAY ON SHAKESPEARE'S RELATION TO TRADITION}

OrIGINALITY was a new and somewhat ugly idol of the nineteenth century. It is true that the Augustans had reverenced "invention" as one of the great poetic qualities; but "invention" was of the manner, decoration: not of the matter. The subject of a great poem, they held, as did their predecessors, must be dug from the soil of the ancient thought of man. "For out of oldë fieldës, as men saith, cometh al this newe corn fro yere to yere." These older writers treat poetry as a natural growth, as something having organic and mysterious life. "As good almost kill a man as kill a good book," cries Milton, and this sense that a great work comes out of the common storehouse of nature, and has the sacredness of birth, is strong in all the greater artists.

It is very marked in Shakespeare, who shows it, for example, by his unwillingness to alter the facts of a story which he has borrowed. 


\section{SHAKESPEARE AND TRADITION}

You cannot generate living things in the mind of one individual: life requires a long descent and a labyrinth of roots connecting it with other atoms in existence. It is perhaps significant of their poetic gift that the Elizabethans almost without exception are great translators.

The novelists of the nineteenth century have much inventive power, but little poetry. Dickens, for example, conspicuously fails in this, and it is interesting to note that he comes nearest to it in the two novels on historical themes, Barnaby Rudge and The Tale of Two Cities. Meredith tries to create the impression of two strata of treatment, so as to get this effect of matter that is already part of life. For example in Beauchamp's Career we see all the time that there is a fairly simple and straightforward story as the basis, though Meredith's novel is anything but simple. Hence we are aware all through (and are intended to be so aware) how another writer would have treated the matter, till we gradually believe that it has been so treated, and regard Meredith's work as the comment on something already known. This gives the depth of poetry.

Shakespeare went a simpler way to work. He always took old matter, at first purely literary, such as older plays, English and foreign - and he continued to use such matter to the 
end. But soon he learned to mix his literary matter with the old folk-dramas, which had the vitality of countless generations in them, and their roots in the far-off mysterious kinship between man and the dumb earth with which his dust mingles in death. The debt is no mere suggestion of the plot, but extends in many cases to most of the situations on the stage, and not infrequently when the source is literary, to the words. But in every case he makes some change that, though superfieially slight, is really like a shifting of the centre of gravity and alters the meaning of every speech. He says "a far other thing in the same words," and the thing he says is sometimes not merely different but a direet denial of the older thought. 



\section{I COMEDY}

I. Types of Comedy before Shakespeare.

II. Evidence of the Influence of Munday ou Shakespeare leading up to Shakespeare's use of tho Folk-play.

III. The traces of Folk-plays in Shakespeare is drama. 



\section{I \\ COMEDY \\ Section I}

TYPES OF COMEDY BEFORE SHAKESPEARE

Comedy at the time when Shakespeare began writing may be said to fall into four classes:

1. There is first the hard, unlovely type, represented at its best by Shakespeare's Comedy of Errors, descended from Latin comedy, with perhaps some slight admixture of the fabliau element. After the Comedy of Errors Shakespeare never wrote a whole play in this style, though traces of it appear in comic sub-plotsas, for example, the scenes with Gobbo in The Merchant of Venice.

2. Much more important is the comedy of Lyly. Examples of direct borrowing have often been cited, but so thin and pale do Lyly's figures look beside the greater master's creations that we are apt to sweep aside the evidence of this debt as fundamentally unimportant. Shakespeare had, however, clearly made a careful study of Lyly's work, and we must 


\section{8}

\section{PRE-SHAKESPEAREAN COMEDY}

allow for the probability that he saw at least as much in it as we do. Now, Lyly's plays are essentially masques; that is to say, they are representations of actual incidents of the time at which they were performed, translated by the language of allegory and symbolism into a more radiant plane of existence. The characters, for example, in Endymion are not fully worked out-merely designated-because the audience knew that Endymion wasLeicester, and Cynthia Elizabeth, and so on. It was not the business of the poet to create, but to flood the given facts with a golden light of poetry which should show all the fairer connections. The masque is, in fact, the direct antithesis of satire. Now, the great comedy of all other literatures belongs to the satirical family-it exaggerates whatever is ugly in human nature in order to make it ridiculous-and Ben Jonson's comedy shows that without Lyly and Shakespeare English comedy would probably have followed the same lines. The scene of Shakespeare's comedy is laid in a golden world, and the suggestion of that ethereal atmosphere comes from Lyly. Lyly failed because he does not at the bottom of his heart believe in his golden world; Shakespeare's task was to give it truth. For example, we may feel that the creation of Viola's twin brother 
to satisfy Olivia is a little improbable, ${ }^{1}$ but it is at least better than Lyly's device of actually transforming a girl into a man to remedy a similar mistake of "Fancy." Still, it is from Lyly that we must start to understand Shakespeare's comedy at its heart, and The Tempest, designed as it seems to be, in its present form, as a more or less personal statement, shows everywhere memories of Lyly's work.

3. Thirdly there is a group of plays whose homogeneity has been somewhat overlookedthose constructed with an Induction. The most interesting is Peele's Old Wives' Tale, but the plays of Munday, The Taming of a Shrew, and the practice of Jonson, show how widespread was its use. It is worth while to examine briefly what seems to have been the artistic theory involved in its use, because Shakespeare apparently repudiated it. The character of the Drunkard in $A$ Shrew was of a kind sure to appeal to him, and apparently he could not find it in his heart to cut him out altogether; but he destroys the effect of an Induction by leaving out the later dialogues with Sly, and, I think, by clearing him off the stage. ${ }^{2}$

1 He found it, perhaps, in Lope de Rueda.

2 Even if $A$ Shrew is, as Professor Raleigh believes possible, Shakespeare's own, it is an earlier version, and the later form must stand as Shakespeare's considered verdict. Now, in the Folio 


\section{PLAYS WITH INDUCTIONS}

The artistic effect of an Induction was that of a frame-work for the play proper: it cut the story of the play off from everyday life and deliberately emphasized the mimic nature of it. This could never be forgotten so long as spectators remained on the stage commenting on the action and suggesting alterations in it. Shakespeare allows Sly to see the beginning of "The Shrew" only, and then he grows more and more drowsy. Surely the intention is that Sly, and not Petruchio and Katherine, shall fade from our minds, like people seen in the street on the way to meet those who really come into our lives.

In three plays-Hamlet, The Midsummer Night's Dream, and The Tempest-the setting of the play within the play takes the place of an Induction, and in each case Shakespeare emphasizes the artificial nature of plays so introduced. The opposite treatment of the form is best seen in William Morris's Love is Enough. There the Induction-or series of Inductions one within the other-leads us by degrees from the material and superficial world to the inner spiritual and emotional world, which is truth.

version Sly enters "aloft" to watch the play, but must have gone by the time that the counterfeit Vincentio looks out of the window. 


\section{INNER PLAY THE CORE OF TRUTH 11}

" $O$ hearken the words of his voice of compassion; Come cling round about me, ye faithful who sicken Of the weary unrest and the world's passing fashion.

As the rain in mid-morning your troubles shall thicken,

But surely within you some Godhead doth quicken

As ye cry to me heeding, and leading you home."

Compare with this treatment of the inner play as the core of truth Prospero's masque and the Athenian clown's play before Theseus. The masque is introduced to amuse the lovers and make them forget their passion for a while in its coloured artificialities. In it Cupid

\section{" has broke his arrows,}

Swears he will shoot no more, but play with sparrows And be a boy right out."

There is no need to labour the ridicule thrown on Bottom's play, but the subject selected for this apotheosis of emotional untruth is perhaps significant. Chaucer appears in Shakespeare's day to have stood for the type of poetry dealing in dream allegory and mystical ecstasy. He was remembered for The Legend of Good Women and Troilus and Cressida, and identified with a sensuous school that worshipped passion as an absolute good, and valued men and women by the degree to which they abandoned themselves to its power. 
Shakespeare portrays such heroines in Cressida :

"Why tell you me of moderation?

The grief is fine, full, perfect, that I taste, And violenteth in a sense as strong

As that which causeth it: how can I moderate it ? If I could temporize with my affection, Or brew it to a weak and colder palate, The like allayment could I give my grief: My love admits no qualifying dross; No more my grief, in such a precious loss."

Shakespeare scems to have had an almost passionate dislike of the school. It is difficult to forgive his degradation of Chaucer's frail, flower-like heroine, who "so sorry was for her untruth," into the inherently corrupt Cressida, whose "wanton spirits look out at every joint and motive of her body."

Nor did he leave it there. The Queen in Hamlet is another version of the Cressida type, and in her Shakespeare has translated Chaucer's pitiful "she was alone, and haddē need of frendës help," into the loose, emotional incontinence and superficiality of the woman who

$$
\text { "within a month, }
$$

Ere yet the salt of most unrighteous tears Had left the flushing in her galléd eyes,"

gave herself to the "bloat King " with nothing to attract her but his gross caresses. 
The argument is, then, that Shakespeare rejected the Induction consciously, because it seemed to him inconsistent both with the nature of his art and with his ethical views. Nevertheless, in the form as practised by Peele he found much to interest him, and I hope to show later that he translated the thought engendered in him by Peele's work into the harmony of the last plays.

4. Lastly, the young playwright had before him the comedy of Greene and of Munday, but the influence of the first has probably been greatly exaggerated, and that of the latter too much neglected. Greene himself is greatly indebted to Munday, and it seems more than probable that Shakespeare's debt is really to Munday altogether. A well-founded dislike of Munday's character is, perhaps, responsible for the unwillingness of critics to do him justice. The quality which Shakespeare is generally supposed to have taken from Greene is just the romantic nature of his comedies, the combination of a story having a marvellous element with the delineations of characters intensely human, often erring, sometimes ridiculous, but always drawn with a sympathy that provokes smiles rather than sarcastic laughter, and suggests a fundamental good-will and harmony in life. It is a curious gift to come from either 
Greene or Munday - the onea dissolute, envious, disappointed man, who seizes the moment of: a tolerably sincere repentance to cast mud at his fellow-craftsman, and who was saved. artistically as well as morally by the quite unmerited good-fortune of a noble wife; the other a spy of the meanest description, who appealed in distress to the sympathies of the very people he meant to betray, and is so utterly without.a moral sense that he explains his methods quite directly in his book, clearly without any idea that any feeling other than admiration of his acuteness will be excited. The attribution to Greene of the idea of harmonious comedy is due, probably, to the feeling that he at least must have known goodness when he saw it. It is true that in James $I V$. Greene seems to have some conception far beyond his childish power of expression; but he was aiming there at creating the history play, his harmony is political:

\section{"These nations if they join,}

What monarch, with his liege-men, in this world Dare but encounter you in open field ?"

His best claim would be founded on George $a$ Greene, should that play ever be ascertained to be his.

When we turn to Munday, we have to deal 
very largely with conjecture; a study of Munday is much to be desired. The certain links with Shakespeare are few, but very interesting. There is the line from the Downfall of Robert, Earl of Huntingdon, "The multitudes of seas dyed red with blood," which suggests at once Macbeth's "multitudinous seas incarnadine, making the green onered." There is the Pedlar's song, which resembles that of Autolycus. Such reminiscences apparently convinced Dr. Ward that "Shakespeare was acquainted with these plays." It is perhaps worth while to gather together other evidences pointing not merely to casual acquaintance, but to a careful and deliberate study of Munday's methods and matter. It is not intended to suggest that Munday's own artistic rank was at all high; but he does seem to have had that kind of originality which strikes out new forms and sees possibilities in directions contemned or unnoticed by men of far greater genius and accomplishment. Munday's execution is never adequate; but, remembering Shakespeare's attitude to Chaucer, and comparing the plays founded on Plutarch with those founded on comparatively worthless material, the conclusion seems plausible that to Shakespeare a work of art approximately satisfying was less inspiring than a faint and hesitating suggestion. 


\section{Section II}

EVIDENCE OF THE INFLUENCE OF MUNDAY ON SHAKESPEARE, LEADING UP TO SHAKESPEARE'S USE OF THE FOLK-PLAY.

Modern editions of The Merchant of Venice seem to have overlooked Douce's mention of Munday's novel Zelauto in connection with the sources of that play. What is still more curious is the slight reference Douce makes to it himself. The book appeared in 1580, and seems never to have been reprinted. Collier, who did some interesting work on Munday, apparently had not seen the book, for he notes it in his list of Munday's work on the authority of Ritson. There is a copy in the Bodleian Library, in the Douce Collection-presumably Douce's own-. and it appears to have been very little read, sc, clean are its pages.

It is in three short books, or chapters, the first two of which are profusely illustrated. though the illustrations do not always fit the text. One picture of three men sitting at table in an arbour is used to represent all the many meals presented to the hero, though on no occasion does he eat with two men alone. The story is unfinished, and does not explain its sub-title of "The Fountain of Fame." It is 
said to be written to welcome Euphues into England, and appeared between the dates of issue of the first and second parts of Lyly's book. The style has clearly been affected by Euphuism, both by its antithesis and by its use of trite sayings; but Munday's dialogue has a certain coarse vigour, and the apothegms, being mostly familiar proverbs or Biblical phrases, give an impression of real conversation such as is very rare in the other novels of the time. "If you set not a point by us, we care not a pin for you, if we may have your goodwill, so it is; if not, keep your wind to cool your pottage." Such is the speech of an unamiable old man to another equally unamiable whom the speaker and his family have overreached; and the literary art displayed is not more objectionably obvious than in much of Scott's semi-comic dialogue. This example is taken from the third book, and it may be noticed that the dialogue is at its best there, a reason for which fact will be suggested later.

Zelauto is a young gentleman of Italy who goes on his travels to improve his mind, as Munday himself professes to have done in the Romayne Life. After many adventures he arrives alone and in a feeble state at the cave of a solitary who rushes out and attacks him. He is defeated and begs for mercy, which"with 
some difficulty he obtains. He then proceeds to relate the story of his earlier adventures to the Hermit, whom, we are told incidentally, is a fugitive from justice.

Zelauto, like his creator, began his adventures by falling into the hands of banditti, who robbed him of all he carried, wounded him, and killed the knight who attended on him. He managed to reach an inn, where the hostess received him with great kindness, gave him her best room, had a large fire lit, prepared a rich repast, and generally showed the interest with which she regarded him. Having obtained fresh funds, he went on his way, and after a time reached England. His sojourn there is the occasion for lavish compliments to Elizabeth, conveyed chiefly by means of the description of a masque or entertainment which Zelauto says was performed before her, and of which there is an illustration. It consists simply in a long argument and then a duel between a knight and a lady champion. The lady upholds the virtues and beauties of Elizabeth against all other claimants, and the knight upholds his own virtues. $\mathrm{He}$ is, of course, defeated. The book ends here.

The second claims to be and really is much more entertaining. Zelauto travels to Turkey, and, as usual, at once wins the favour of the 


\section{ZELAUTO}

mistress of the house where he lodges. She is a Christian, and her husband is converted to that faith by the teaching of Zelauto, but secretly, for fear of the Turks. However, Zelauto is forced into a public confession, for a certain lady of the city, having become a Christian, is condemned to be burned to death. Zelauto undertakes to fight as her champion, and it is remarkable that Munday makes his hero extremely unwilling to risk his life. But, all efforts to achieve his purpose by other means failing, he fights the duel, slays his antagonist, and the lady is released. Zelauto himself, however, and his unfortunate host are both imprisoned and condemned to death. The host is executed immediately, but Zelauto is granted a few days' grace, and the brother of the rescued damsel, together with a new female admirer, the wife of the gaoler, contrive his escape in a thoroughly comfortable manner, stealing a large sum of money for him. At this point the Hermit goes to prepare dinner, and leaves Zelauto with a manuscript which forms the third book.

The scene of the Hermit's tale is Verona. Strabino, the son of a wealthy citizen of Pescara, has come to the University of Verona to pursue his studies. He there forms a close friendship with a young man called Radolfo, and is in 
due course introduced to Radolfo's father and his sister Cornelia. With Cornelia he falls in love, but she has a considerable amount of character, and he is in doubt as to her feeling. The conversations are far less dull than those in Euphues because of a real independence in Cornclia. "Ah, signor," she exclaims, "though you have all the learning, God hath lent us some wit, that we should not be too much decoyed. . . . If you like us, love us; if not, leave us alone." Again, she says of herself that she "is wedded to her will, and married to her own mind." But now there comes on the scene an old usurer, Truculantos, who wishes to marry Cornelia, and bribes her greedy father to support his suit. Strabino and Radolfo find her in despair. Strabino declares his love, is accepted, and the three young people arrange a plot. Radolfo, taking Strabino with him, goes to Truculantos' house, and borrows 4,000 ducats for a month, the forfeit to be the estates of both young men and the right eye of each. With the money they buy a rich jewel, which Strabino presents to the greedy old father, and induces him to throw over Truculantos and receive himself as a sonin-law. Radolfo has meanwhile fallen in love with Truculantos' daughter Brisana, and obtains her hand from her father, who does not 
yet know of the trick played on him. When he does hear the truth he comes to old Ruscelli "as one bereft of his wyttes, or as a man feared out of his five senses."

Obtaining no satisfaction, he resolves on vengeance, and the young men, apparently from forgetfulness, having passed the day when the debt is due, he summons them to pay the forfeit. The scene in court is described in full. The two wives dress themselves like "Schollers" and go with their husbands as their attorneys, being apparently unrecognized by all in court. The Judge appeals to Truculantos' better self, in a speech which seems to be the origin of Portia's mercy speech, and which has more chance of touching Truculantos, since he is apparently a Christian. "Why, Truculantos, respect you cruelty more than Christian civility, regard you rigour more than reason? Should the God above all gods, the Judge above all judges, administer desert, which your sins hath deserved; if His fatherly affection, if His merciful mildness, if His righteous regard, did not consider the frailty of your flesh, your promptness unto peryll and your aptness unto evyll; how mighty were the miserie which would justly fall upon you ! How sharp the sentence that should be pronounced against you !... Is this the love 
you bear to your brother? Is this the care you have of a Christian? You, a branch of that blessed body which bare the burden of our manifold sins, how can you seem to deal so sharply with yourself, seeing you should use to all men as you would be dealt withal ?" Truculantos still demands his bond, and Brisana is allowed to plead. Her point is that Truculantos was not at home on the day when the bond was payable, but the usurer, though shaken, still stands to the fact that payment had not been offered to his representative. Then Cornelia gives judgment in his favour, but says that he must take the eyes himself, and that, without shedding a drop of blood or taking more or less than the eyes, since the bond mentions eyes only; and so "if you take more than you should or less than you might you shall abide the punishment here in place pronounced" -namely, the loss of both his own. The usurer is furious, but " desired he might have his money, and so let all other matters alone. Nay (quoth the Judge), since ye would not accept of it when it was offered . . . the money shall serve to make them amends for the great wrong which you would have offered." This ends the book.

Now, this story was printed in 1580 , before even Marlowe's Jew of Malta. There is an 
Italian story in some points nearer The Merchant of Shakespeare, but it is not known to have been translated into English till our own day, though the Italian version was published in 1558. The usurer in it is a Jew. Clearly Munday, who had been in Italy and knew Italian quite well, got his story from San Giovanni, whoever he was, for it appears to be a mystery. But Shakespeare must have had both versions before him, for while San Giovanni's story gives certain details which Munday's does not, the " mercy" speech is more likely to have been composed originally for the story with a Christian usurer. Munday may have told Shakesspeare the original story, but I incline to believe that he had made a play of it. Gosson speaks in 1579 of two plays, which he calls two "prose books played at the Belsauvage, where you will find never a word without wit, never a line without pith, never a letter placed in vaine. The Jew and Ptolome, shown at the Bull, the one representing the greediness of worldly chusers and bloody minds of usurers, the other very likely describing how seditious states . . . are overthrown." Douce believes this play to be Shakespeare's source, though he does not connect it with Munday. It has often been pointed out that the description which appears to be that of the Jew would apply fairly well 
to our play, but except in the fact of the usurer being a Jew, it would also apply to Munday's story, wherein the worldly greed of Ruscelli is strongly emphasized. The hand of his daughter is to be given simply to the suitor who gives her father the most attractive gift. Munday used the same matter in other cases more than once with certain alterations. And there is another suggestion, that Munday had written the tale first as a play. I pointed out that the dialogue in this third book is remarkably vigorous, and the speeches in the Trial scene at least are of a quite reasonable length and very much to the point. Now, Elizabethans knew how to write dialogue for the stage, they did not as a rule for prose narrative, and it seems therefore probable that Munday had a play before him.

Again, there is strong though not conclusive proof that Munday translated an Italian play, which he called The Two Italian Gentlemen, or Fidele and Fortunio, and which furnishes fairly clearly the skeleton of Shakespeare's romantic comedies, more especially of the Two Gentlemen and also of Romeo and Juliet. There is an old woman who plays much the part of Juliet's nurse, and whose morals are quite as bad. There is a waiting-maid whose reception of a lover casts suspicion on her mistress, as 
THE TWO ITALIAN GENTLEMEN 25

Margaret's does on Hero in Much Ado. There is a balcony scene that has certain resemblances to Juliet's-scenes that remind us of the serenading of Sylvia and others; a churchyard scene; and finally the conduct of the two Gentlemen to each other, and the extraordinarily awkward dénouement, is very much the same as in Shakespeare's play. It is noteworthy that to the end of his life Shakespeare seems scarcely able to picture a passionate love story as having for scene any place but Italy; the situations of his comedies suggest the manners of a southern climate, and the lovers whisper to each other in the moonlight of Italian gardens.

The question of Munday's influence on Shakespeare's development is of so much importance that a short digression is necessary to establish his authorship of this translation. We know a certain amount of Munday's views, and certain aspects of Shakespeare's work acquire a new significance if they can be traced to his connection with the other dramatist.

The translation is by A. M., and Collier claimed to have seen a dedication signed in full Anthony Munday. But this dedication is not extant, and Collier's forgeries have cast suspicion on all those statements of his which are not otherwise corroborated. We must rely on other evidence. 
Now in Much Ado About Nothing there is a very curious passage unlike Shakespeare's writing, and possibly not by him, but even in that case fairly good evidence. The passage occurs where the Watch overhears the conversation between Don John's scoundrelly followers :

"Borachio. Thou knowest that the fashion of a doublet, or a hat, or a cloak, is nothing to a man.

Conrade. Yes, it is apparel.

Bora. I mean, the fashion.

Con. Yes, the fashion is the fashion.

Bora. Tush, I may as well say the fool's the fool. But seest thou not what a deformed thief this fashion is ?

Watch. (Aside) I know that Deformed; a' has been a vile thief this seven year; a' goes up and down like a gentleman: I remember his name.

Bora. Seest thou not, I say, what a deformed thief this fashion is? how giddily a' turns about all the hot bloods between fourteen and five-and-thirty? sometimes fashioning them like Pharoah's soldiers in the reechy painting; sometimes like god Bel's priests in the old church window; sometimes like the shaven Hercules in the smirched worm-eaten tapestry.

Con. All this I see. But art not thou thyself giddy with fashion too, that thou hast shifted out of thy tale into telling me of the fashion?

Bora. Not so, neither; but know that I have tonight wooed Margaret, the Lady IIero's gentlewoman, by the name of Hero.

First Watch. We charge you in the prince's name, stand ... and one Deformed is one of them: I 
know him, 'a wears a lock (Much Ado, III. 3, 124151).

Dogberry. And also, the Watch heard them talk of one Deformed; they say he wears a key in his ear and a lock hanging by it, and borrows money in God's name; the which he hath used so long and never paid that now men grow hard-hearted, and will lend nothing for God's sake" (Much Ado, V. 1).

The first of these passages is for about twentyfive lines of the nature of a digression, and a digression with curiously little point, as Conrade says. When abstract discussions occur in Shakespeare's plays, the interlocutors are usually important persons and the discussion serves to display their characters. Such, for example, is Hamlet's criticism of plays and of players. Again, wit-combats, it is true, are frequent in the early plays, and are often in a sense pointless enough; but they are the sallies of youth, and their very nonsense gives the effect of high spirits as better wit could not do. We feel with Mercutio that this is " better than groaning for love." The very essence of youthful society is in the "wild-goose chase"; and we learn to love both Mercutio and Romeo as we listen to their absurd puns. But the passage from Much Ado seems to have no such artistic justification. It is a passage suggestive of Ben Jonson's topical plays in style; the fun of the Watch's mistake could 
have been managed with a couple of lines from Borachio, and we have no desire at all to see more of the two unattractive followers of Don John than is needful for the story. Further, Dogberry's elaboration in the later scene of the lock which Deformed wore, into a "key in his ear and a lock hanging by it," may easily be that sage's gloss on what was originally a mere love-lock, but nothing in the earlier scene suggested the detail that Deformed "borrowed money in God's name." Fleay long ago suggested that Deformed is Shakespeare himself, and explained the nickname as a reference to his Richard Crookback. An allusion of Kempe's gives some little corroboration. But the name Amorphous, translated several times in the play Deformed, occurs in Ben Jonson's Cynthia's Revels, and there can be little doubt that this, like so many of Ben Jonson's dramas, owed some of its appeal to personal allusions. Now, Amorphous is generally referred to as the "traveller"; he is the discoverer of the Fountain of Self-Love, and boasts that he has "invention" above Crites, who is almost certainly Jonson. For these and several other reasons it is fairly safe to accept the identification of Jonson's Amorphous with the dramatist, pamphleteer, and ballad-writer, Anthony Munday. Munday had 


\section{AMORPHOUS AND DEFORMED 29}

been praised by Meres as "our best plotter," and this praise was bitter to Jonson, who considered invention his own greatest gift. $\mathrm{He}$ satirized Munday again in The Case is Altered (or possibly before), and sneered at him for being "in print as the best plotter." Amorphous' boast of his "invention" looks like another gibe on the same point. .

Again, the Fountain of Self-Love might be an allusion to the sub-title of Zelauto-the Fountain of Fame. The hero of that novel is pretty obviously a very glorified portrait of Munday himself, and his adventures a still more idealized account of that period in his own life which Munday professes to describe in The Romayne Life. Zelauto's way is smoothed by a long series of ladies who take a romantic interest in him, while Amorphous tells us that he has " been fortunate in the amours of 345 ladies, all nobly, if not princely descended; whose names I have in catalogue."

Let us, then, accept the identification of Dogberry's "Deformed" with Munday, as a working hypothesis. At once we get a meaning for Borachio's assertion that he has not shifted out of (his) tale" in talking of the deformed thief, for the incident which he goes on to relate is taken from Fidele and Fortunio. Borachio has not shifted out of his tale, for the 
trick he has just played on Claudio is exactly the same as that played by the follower of one of the Lovers in the Two Italian Gentlemen on his rival. The drift of Borachio's thought is that even villainy has its fashions; it cannot invent a new trick, but must needs steal the idea from another. Shakespeare, it is true, laughs at the Watch's personal application, but one should note that the Watch, asses though they be in speech, are acute enough in fact. Borachio and Conrade were hatching villainy, and their evil plot is frustrated by the Watch's prompt action. Dogberry's gift of speech makes communication difficult, but the information he has to impart is of real value. It seems, therefore, probable that, though the process is all wrong, the conclusion that someone nicknamed the Deformed, and with a doubtful reputation, was the author of the incident of the impersonated wooing is true enough, and the details fit Munday exactly. He was a spy and informer against the Roman Catholics, hence "the key in his ear and the lock hanging by it." In The Romayne Life he tells us himself that he borrowed money again and again from Roman Catholics on the plea that he was an honest inquirer travelling to Rome to be instructed in that creed. This would explain the point that he "borrowed 
money in God's name." He also tells us that he passed himself off in Rome as the son of a Roman Catholic gentleman who had an estate in the Midlands, which agrees with the Watch's statement, "a' goes up and down like a gentleman." Munday was not a "gentleman." His father seems to have been a draper and citizen of London, and Anthony calls himself a draper in some of his books. It seems fair, therefore, to accept Collier's attribution of The Two Italian Gentlemen to Munday, and we may even, perhaps, see in the passage an acknowledgment by Shakespeare of the attractive genius of this rogue, who " turns giddily about all the hot bloods between fourteen and fiveand-thirty."

Now, Munday seems to have been a person of some originality. The nickname Balladino refers, apparently, not merely to his production of doggerel for the state occasions of the City of London, but also to some special claims which he put forward for the real old folk-ballads. For Munday seems to have gone to such ballads, folk-drama, and folk-lore, for some of the matter of his plays. Balladino tells the admiring Onion:

"I do use as much stale stuff, though I say it myself, as any man does in that kind. . . . I write so plain and keep that old decorum, that you must of necessity 
like it; marry, you shall have some now (as, for example, in plays) that will have every day new tricks, and write you nothing but humours; indeed, this pleases the gentlemen, but the common sort they care not for it; they know not what to make on't; they look for good matter they, and are not edified with such toys.

"Onion. You are in the right. I'll not give is halfpenny to see a thousand of them. I was at ons the last term; but an ever I see a more roguish thinis I am a piece of cheese, and no Onion: nothing but kings and princes in it, the fool came not out a jot.

"Balladino. Tut, give me the penny, give m" the penny. I eare not for the gentlemen, I; le; me have a good ground, no matter for the pen, thes plot shall earry it."

This satire is borne out by Munday's owr work. In particular, there is a play of his. extant on that version of the Robin Hood story which makes him Earl of Huntingdon. It is not a great play, and much of its interest is due to the idea that it may have suggested As you Like It to Shakespeare. It seems almost certain that Munday did direct the great dramatist, but the debt I believe to have been mainly of a different kind from that supposedor possibly to an earlier play.

In the course of Robert, Earl of Huntingdon, the author stops to justify his treatment of the story in a way which implies that there were in existence. and presumably on the same stages, 


\section{MUNDAY AND ROBIN HOOD PLAYS 33}

plays quite near to the Robin Hood plays of the country drama-possibly adapted for the town by Munday.

The caviller objects:

"Methinks I see no jests of Robin Hood, No Merry Morices of Friar Tuck, No pleasant skippings up and down the wood, No hunting songs, no coursing of the buck."

And Munday answers: "For merry jests they have been shown before." It is not clear whether by him or another, but it looks as if what were in origin country games or rites had actually been transferred to the professional stage. In any case, his service in this particular to Shakespeare was, I believe, to suggest to him that these games, in origin faded pagan rites, were a worthy subject of art.

Robin Hood seems to have been something of an obsession with Munday, and it may therefore not be without significance that Shakespeare twice uses the outlaw motive in his comedies: in The Two Gentlemen of Verona (which, we have seen, is probably otherwise indebted to Munday) and in As You Like It. The name of Robin Hood is mentioned, however, merely in passing. What Shakespeare gets is the suggestion of the free life of the forest. The effect of this natural back-ground 
in The Two Gentlemen of Verona is almost magical. Fidele and Fortunio is an amusing play enough, but its scene is laid entirely in the streets and houses of a town, and the superficiality of the emotions of the characters is well suggested by the trick which gains Fortunio's desire. Outraged convention forces him on the unwilling Virginia, but apparently her heart goes with her hand. Shakespeare transfers this fickleness of fancy to the man: nothing so distinguishes him from the mediæval artist as his belief in the profound nature of a woman's affections. Even Chaucer had said:

"For women-for to speken in commune They folwen aye the favour of fortune."

In Shakespeare's play, though the abruptness of Proteus' conversion shows the crudeness of early work, the sense that among the outlaws in the forest all the restraints of conventional life are necessarily broken, and human passions take their natural course, gives at once a reality and a depth of meaning to the play.

The other play linked with the Robin Hood story is, of course, As You Like It. Whether Shakespeare had ever seen a version of the Gamelyn story, the ultimate source of the Orlando incidents, is doubtful and not very important. He is, again, not interested in 
the Robin Hood story for itself. What he aims at getting is the natural backgroundthe sense of the oneness of the human and the inanimate world around. He gets this feeling partly by steeping his Arcadian story in the customs and scenery of his native countryside. It is likely enough that Munday suggested it, but there is no proof whatever that any comedy written before Shakespeare consistently followed the plan of combining a more or less literary story with a folk-play. That Shakespeare did so is suggested by the following examples.

\section{Section III}

THE TRACES OF FOLK-PLAYS IN SHAKESPEARE'S DRAMA

There is in As You Like It a curious little scene much scorned by Samuel Johnson, and, as it does not occur in Lodge's Rosalynde, apparently one of Shakespeare's additions to the play. It is eighteen lines in length-much too short to suggest the fairly long interval required at the point-from which it seems probable that there was a good deal of business, possibly dancing. Jaques asks, "Which is he that killed the deer?" and goes on, "Let's 
present him to the Duke like a Roman Conqueror; and it would be well to set the deer's horns upon his head for a branch of victory. Have you no song, forester, for this purpose?" "Yes, sir."

“Jaques : Sing it: 'tis no matter how it be in tune, so it make noise enough."

"What shall he have that killed the deer? His leather skin and horns to wear.

Then sing him home. (The rest shall bear this burden.)"

" Think thou no scorn to wear the horn;

It was a crest ere thou wast born, Thy father's father wore it, And thy father bore it.

The horn, the horn, the lusty horn, Is not a thing to laugh to scorn."

Now, that is the whole scene. It would mean a good deal of preparation, and, unless there was much business, it would fill very little time. Nor can the song be said to be of much merit. Its sole purpose does seem to be to make a noise. But, on the usual hypothesis, Shakespeare deliberately inserted it. Now, if we turn back to Munday's description of a real Robin Hood play, we find that this scene would meet that ideal-it required skippings up and down the wood, hunting songs, and coursing 
of the buck. And there is a further curious fact. Chambers in his Mediceval Stage (vol. i., p. 166), mentions that in Staffordshire at Abbots Bromley there is a dance customary formerly at Christmas, at which six of the performers wear horns, and these horns are preserved from year to year in the church. Now, it is at least curious that Shakespeare's song would be quite appropriate to men so dressed. The Staffordshire dance is, of course, part of the primitive drama, and Shakespeare's rather meaningless and ribald song becomes at once full of interest if we regard it from this point of view. There are other suggestions of the folkplay-for example, the serpent so oddly found in Arden may be the dragon of many of those plays, the wooing of Rosalind by Orlando may be suggested by the wooing of Cicely (e.g., in the Lutterworth play), and, finally, the general mating at the end is like the linking up of couples in a country dance.

It is to be noticed that this particular scene is introduced by Jaques, and that, in fact, whenever the huntsmen sing Jaques is always present, and generally asks for the song, though he does not apparently sing himself. This makes him extremely like the leader of a morrisdance. We shall have to return to Jaques afterwards, but first we must see what traces 
there are of this being a consistent policy on Shakespeare's part.

I shall not attempt to follow chronological order. My object is to suggest that after the composition of The Two Gentlemen of Verona Shakespeare used a folk-play habitually as the nucleus of his comedies.

Chambers, in his Medioeval Stage, comes to the conclusion that there were five great folkfestivals, originally primitive religious feasts, but disguised and overlaid by Christian doctrines and customs. The five are-(1) The Winter Feast, lasting from All Souls' Day to Twelfth Night; (2) the Ploughing Feast, held at Candlemas or at Shrovetide; (3) the Feast of the Beginning of Summer; (4) the High Summer Feast; (5) the Harvest Feast, at Michaelmas.

Now, Shakespeare has a play called Twelfth Night, and one which proclaims its connection with the High Summer Feast. There are reasons for connecting All's Well that Ends Well with the Shrovetide or Hocktide celebrations; while The Winter's Tale suggests the Harvest Feast, and As You Like It is perhaps more especially the May Feast.

All's Well is best dealt with first.

There were two elements in the Hocktide festivities: one was a struggle for a head or 
hood, which, at Coventry at least, had developed into a mock representation of a battle between the Danes and the English. In this form it was "played" before Queen Elizabeth. At Haxey, in Lincolnshire, a struggle takes place for a " hood " or roll of leather representing probably the head of a sacrificial bullock. The other part of the ceremonies was the " hocking" of men by women. "On Hock Monday the women ... went abroad with ropes, caught and bound any man they came across, and exacted a forfeit."' The next day the men could retaliate, but this does not seem to have been so common. Forfeits and fines were a regular feature of the proceedings.

If we turn to All's Well, we find there also two elements: (1) The story of Helena's capture of a husband, with the assistance of all the other women in the play; (2) the story of Parolles, the chief part being the long scene at the Florentine seat of war.

The story of Helena has two main episodes: (1) Her cure of the King, and his ransom of

1 In 1549 two men were smothered at Shrewsbury by some kind of landslip as they were hiding themselves from the women. The household books of Edward I. record in 1290 a payment to seven ladies of the Queen's chamber, who "took the King in bed on the morrow of Easter and made him fine him. self" (Chambers). 
his own life by the gift of any unmarried noble as her husband; (2) the trick whereby she finally gains her husband, which is in the nature of a forfeit. "When from my finger you can get this ring," says Bertram, " call me husband;" and he is supposed to redeem the forfeit with his love. This is clearly very like the hocking.

The second element is the story of Parolles the boaster. He gives out that he is going to take a certain trophy from the enemy, but the lords who are acting under Bertram, realizing his cowardice, lay an ambush for him and take him prisoner, blindfolding him at once so that he may believe himself with the enemy. They also talk gibberish to simulate a foreign tongue. When he has, as he thinks, betrayed all the secrets of the army to the enemy and slandered everyone present, he is unhooded, and with mocking salutes those he has abused leave him. If they knocked him about like a human football, as he richly deserved, the analogy would be clearer even than it is. But it seems probable that in some earlier version of the play this may have been the case. When we next meet Parolles (Act V., scene 2), he is in a piteous plight, having apparently been ducked in a foul pond, but the author of his plight is not named. It is not suggested that such a scene as this was the origin of the Haxey Hood 
contest, but that a folk-play on these lines may have been evolved to account for the custom. Chambers refers to a "local ætiological myth about a lady who lost her hood on a windy day, and instituted the contest in memory of the event." Our scene is a better myth than this, and takes in the variant of foreigners being concerned. It is perhaps worth noting that, when Parolles is brought in, Bertram exclaims, "Hoodman comes."

The mid-Winter Feast, says Chambers, " extended from All Souls' Day to Twelfth Night." It was the Feast of Fools, and the essence of its customs was the mocking imitation of all usually held most sacred. The festivities were conducted under the guidance of an individual with various titles, but at Court the Lord of Misrule. The Lords of Misrule in Elizabeth's time were generally at variance with the permanent official called the Master of the Revels, whose primary function seems to have been the custody of the dresses and other valuable properties required for Court entertainments. The Lords of the Council had to interfere occasionally to compose these disputes.

Twelfth Night is a Court play, and it seems unlikely that there is any definite folk-drama behind it. On the other hand, the resemblance 
of Sir Toby Belch to the titular Lord of Misrule is glaring, and his relations with Malvolio may even be founded on those of two historical personages. It is notable that the Master of the Revels had an official under him known as the Yeoman of the Wardrobe, and Malvolio, communing with himself on the possibility of his marriage with Olivia, says (Act II, scene 5):

"There is example for ' $t$ : the Lady of the Strachy married the Yeoman of the Wardrobe."

The foundation of the play seems to be the usual revels woven into a consecutive story. The clown dresses up as a "minister" -i.e., a parish clergyman; Malvolio is induced to assume the conventional guise of a lover; Viola becomes a man. Olivia's bereavement is a curious hint of the connection with the Feast of All Souls.

The identification of this play is interesting both because it would help to prove that Shakespeare did as a practice found his comedies on popular games, and because, the essence of the feast being mocking imitation, it seems probable that, among others, the solemnities of the stage would be parodied. If this is so, Malvolio may be a double caricature-on the one hand of the Master of the Revels, and on the other of the early Hamlet. He is naturally melancholy, is dressed in black, and is supposed 
from his extraordinary antics to be mad. It is true that black was the ordinary dress of a steward, but that makes it all the more likely. If the ideal hero of melodrama appeared as a rule in evening dress, a satirist would certainly make him a waiter. Malvolio's interview with Olivia, in which he tries to establish an understanding with her, may perhaps be a caricature of that interview between Hamlet and Ophelia which the latter describes to her father.

The Midsummer Night's Dream is another play whose name suggests a link with a folkfestival. English folk-lore connected the fairy king and queen with Pluto and Persephone, as may be seen in the romance of Sir Orpheo, perhaps in Greene's Induction to James IV., and in many other places. In the Midsummer Night's Dream the whole play leads up to the final beautiful scene in which, after Puck has swept away the dust, the fairies enter to bless "with field-dew consecrate" the bridal beds and their expected births. When we remember the old Greek ritual mating of a young man and woman who lay out in the fields all night, one suspects that some such custom may be the foundation of the lovers' night in the wood. Douce quotes a passage from Fetherston's Dialogue agaynst Light, Lewde and Lascivious Dancing, published in $\mathbf{1 5 8 2}$. "The third abuse 
of morris dancing is, that you (because you will loose no tyme) doe use commonly to runne into woodes in the night time, amongst maidens, to fet bowes."

Even for Bottom's relation to Titania there was perhaps a hint in the midsummer merrymakings. In the copper-plate engraving of Israel von Mecheln, which Douce reproduces and dates about 1470, is a figure of a fool with ass's ears. Douce believes the original to have been a pattern for goldsmith's work. The trunk of a thorn-probably a may-tree-forms the centre of the design, and on it stands the single female figure looking down at the assheaded fool, who returns her gaze. The conventionalized branches of the tree alone connect the other six figures who are all apparently stock characters of the morris-dance. Douce calls the female figure the Lady of the May, and if he is right the connection with Persephone, and so with Titania, is direct enough. If the picture is at all typical, one surmises that a love scene between the Lady of the May and an ass-headed fool was a regular feature of the morris dance, and Shakespeare has offered here, as in $A l l ' s$ Well, a charming ætiological story.

Although it is an early play, I have left the connection of The Merchant of Venice with folk-drama till the last, because the link is of 
an illusive and tantalizing kind. It is probable that the casket story comes from folk-tales, but there are indications that the Merchant himself is the most important link. He seems to be an addition of Shakespeare's own, for in all the possible sources it is the debtor himself who is to pay the forfeit. In Zelauto two men are involved, but they have both borrowed money. And Shakespeare has left him somewhat enigmatic. He passes out of the play at the end a curiously dim figure for one who has given his name to it and acted so important a part. He has certain remarkable resemblances to Jaques. He has the same unexplained melancholy. The play opens on the note

"Antonio. In sooth I know not why I am so sad:

It wearies me; you say it wearies you:

But how I caught it, found it, or came by it, What stuff 'tis made of, whereof it is born, I am to learn."

Later in the scene we find him giving the text, as it were, of Jaques' well-known speech, "All the world's a stage." Antonio says to his friend:

"I hold the world but as the world, Gratiano; A stage where every man must play his part, And mine a sad one."

What, then, is this part? He is a seapegoat -one who is to pay with his life for the debt 
of another, because, as he himself expresses it, he is " a tainted wether of the flock, meetest for death."

Jaques is also an addition of Shakespeare's to the material supplied in Lodge's Rosalynde. $\mathrm{He}$, too, is melancholy, and, as we learn from the Duke with some surprise, "has been " libertine," "has caught with licence of free foot" "all embossed sores," "and headed evils." His character is developed with considerable, detail, and yet he has no story of his own. These peculiarities taken together put Jaques into a particular class, that of the Fools, and we remember that he himself cries, " $O$ that $I$ were a fool !" On the other hand, it has been suggested that Jaques is not unlike a slighter Hamlet, while Marston's Antonio, who is clearly a double of an early Hamlet, has a speech which must be either the copy or the model of that of Jaques:

"Jaques. I am ambitious for a motley coat.

Duke. Thou shalt have one.

Jaques. It is my only suit;

Provided that you weed your better judgments

Of all opinion that grows rank in them

That I am wise, I must have liberty

Withal, as large a charter as the wind,

To blow on whom I please . . .

Invest me in my motley; give me leave 
To speak my mind, and $I$ will through and through

Cleanse the foul body of th' infected world, If they will patiently receive my medicine."

Antonio appears dressed as a fool to allay his enemies' suspicions, and when his friends remonstrate with him on the indignity, he cries :

"By wisdomes heart there is no essence mortal That I can envie, but a plump cheekt foole:

0 , he hath a patent of immunities Confirm'd by custome, seal'd by pollicie, As large as spatious thought."

The source of Shakespeare's fools is uncertain. Lope de Rueda seems to have introduced them into his comedies in something the same way, and it is possible that Munday imitated the Spaniard, and Shakespeare Munday. The large space devoted to the fool, we learn from Ben Jonson, was one of Munday's peculiarities. But on the whole the allusions suggest that Munday's fool was connected rather with that of folk-drama than with the official kept in royal and noble families, and Jaques, at least, is more the fool of the folk-play. That personage is the most important character, and is at once the centre, chorus, and manager, of the action. An American writer has pointed out that the way in which Jaques pronounces 


\section{TRACES OF FOLK-PLAYS}

the disposition of all the dramatis personce at the end of As You Like It makes him appear the prime mover of the action.

But we remember Jaques chiefly for his melancholy, and it is at least suggestive to find reasons for this in the folk-play. The Revesby Sword-play is one of the best examples extant, the version we have dating from the eighteenth century. In it the fool's sons tell him they are about to kill him. He complains that they are ungrateful, and then, apparently to postpone the evil moment, he bequeathes to them his possessions one by one. The sons then sing:

"Now, old father, that you know our will, That for your estate we do your body kill. Good people, you see what we have done, We have cut down our father like the evening sun; And here he lies all in his purple gore, And we are afraid he never will dance more."

However, he promptly does rise, and a new motif begins.

The Fool and his sons all woo a certain Cicely in turn. When the Fool comes to do his wooing, he says: "My name is noble AnthonyI am as melancholy as a mantle-tree."1 The

1 Mr. Tiddy of Trinity College, Oxford, has shown so conclusively the amazing process of corruption and misunderstanding which has produced most of 


\section{THE REVESBY SWORD-PLAY}

wooing goes on for a long time, and its only importance is the support it gives to the view -for example, of Mr. Cornford-that the primitive drama began with a tragedy and ended with the comic motif of marriage. There is practically no doubt that the Fool who is cut to pieces by his sons "like the evening sun" is in origin the old year, and his resurrection is the regular feature of such primitive rites. When thus brought to life again he is the new year. In some variants it is not the Fool who is killed, but another person whom he claims as his son; or, again, the person who plays the part assigned to the Fool is sometimes called the King. In every case we can see dimly the story of the decay and death and rebirth of life in man and beast, and dumb nature.

But if the Fool of the sword-plays is connected with Jaques, he is still more clearly connected with Lear. It is possible that the Elizabethan folk-plays showed their origin more plainly than those to which we have access. In any case King Lear seems to prove

the dialogue in the folk-plays, that I am not prepared to lay much stress on the actual words found in only a single instance. The action, however, is certainly primitive, and such a common motive of dialogue as the bequests is important. 
that Shakespeare had grasped their meaning. The play is not structurally a tragedy; the death of Cordelia is only inevitable because human life is essentially tragic. And, indeed, not only was Shakespeare's play always acted during the eighteenth century with a happy ending, but the old drama, which is his literary source, does not and could not end tragically. The germ is the old fairy tale of the man with the three daughters, the youngest of whom is the most amiable, while the two elder have every evil quality. Its origin seems to be prehistoric, and it has been called a nature-myth. In the older play the fairy-tale element goes more or less all through. Cordelia dressed as a shepherdess, having been cast out by her father, meets the young King of France, who is also disguised, and they fall in love at first sight. Their love-making reminds one of the Nut-brown Maid ballads, and Cordelia goes away with her lover to become Queen of France, and return later to rescue the old King from his wicked daughters, which she triumphantly does. The story is just of the sort that Shakespeare might have worked into a reconciliation play, and this is the only case known to us where he changes a happy into an unhappy ending. I believe that he began the play as a comedy, or its equivalent in his last period 


\section{THE FOOL OF THE SWORD-PLAYS 51}

of activity - a romance. Being a comedy, he followed his usual method, humanizing his literary source by steeping it in a parallel folkplay-in this case the Elizabethan equivalent of something like the Revesby sword-play. As he studied he realized what was probably more evident in the Elizabethan form of the swordplays, that the story of the Summer King, or Fool who is slain, is the story of pitiful human decay and death, of the passing of the generations. And so in King Lear he portrays the agony and rebellion of the individual when he realizes that the kingdom is passing from him, that in the nature of things he can no longer be the centre of the little group around him. "Sons being of perfect age and the fathers declined, the father should be as ward to the son," says Edmund, putting the words into his brother's mouth, and the sentence makes clear, as the sub-plot always does in this play, the ugly logic of the main story. Lear seems, in one place, to be called "this great Decay."

The alterations that Shakespeare makes in the introductory scene are significant. In the older play Goneril and Regan are still unmarried, and Lear has a right to think that he is still the centre of their lives. But Shakespeare wished to show that it was not merely the accidental and exceptional 
hard-heartedness of his daughters that was the root of the tragedy, but the law of nature and of life. Cordelia points out that her sisters can no longer really look on their father as the pivot of their lives, and that the declaration Lear demands from herself is an attempt to cramp her development and to cut her off from the future:

"Why have my sisters husbands, if they say They love you all? Haply, when I shall wed, That lord whose hand must take my plight shall carry Half my love with him, half my care and duty:

Sure, I shall never marry like my sisters, To love my father all."

One remarkable change that Shakespeare makes has the effect of bringing us face to face with " the mystery of things." The old author was very pious and Christian-Shakespeare makes a definite effort at a pagan atmosphere. For example, the older writer makes Lear say:

"Ah, my true friend in all extremity, Let us submit us to the will of God: Things past all sense let us not seek to know. It is God's will, and therefore must be so."

Shakespeare knows nothing of such pious resignation. He faces the pity and terror of life:

"As flies to wanton boys are we to the gods: They kill us for their sport." 


\section{II}

\section{TRAGEDY AND CONCLUSION}

I. The Greek Tragic hero.

II. The pre-Shakespearean and Shakespearean tragic hero to the earliest Hamlet. Honour the subject of Elizabethan tragedy. Shakespeare's rejection of the superman.

III. A digression to suggest the way in which postShakespearean tragedy is still occupied with the same conception in a narrower form.

IV. The later Hamlet and King Lear.

V. Conclusion: The individual is essentially tragio; consolation is only possible when we regard all life as one. 



\section{TRAGEDY AND CONCLUSION}

\section{Section I}

\section{THE GREEK TRAGIC HERO}

Aristotre seeks for the definition of tragedy when in truth he should rather have studied the tragic hero. The definition of the form led to an analysis in which the life of the thing escapes us; the study of the hero must have led in the end to the haunting atmosphere which is his essence and the soul of the form itself.

Orestes is the typical hero of Greek tragedy. His character is more clearly marked and fixed than any other, and as a matter of mere arithmetic he is a leading figure in no less than seven of our extant tragedies, including the trilogy recognized as the greatest.

With Orestes we must compare Edipus, the hero of the most perfectly constructed drama. Antigone, Iphigenia, and Medea represent the heroines, and Prometheus and Heracles the 
divine subjects of a tragedy. It may be noticed, however, that both Prometheus and Heracles are stained with our humanity; no true god is the hero of a tragedy, for it is Pentheus, and not Dionysus, who is the tragic centre of the Bacchoe. What, then, is the character of the tragic hero?

Now the features common to Orestes and Edipus are that they have both committed appalling crimes against their parents, though both are morally innocent, and that both are driven out in the end to wander in alien lands, haunted figures touched with madness, and a strange supernatural horror:

"Exiled and more am I, impure, A murderer in a stranger's land."

The Oresteia, it is true, closes with the cleansing of Orestes and his reconciliation with the gods, but all Greek story knows Orestes as wandering for ever in far-off barbaric lands. It may have been the invention of some poet consciously breaking with the tradition, but perhaps the solution belongs rather to an ultimate moral world outside the story of our human doings. The justification of Orestes in Aschylus and Euripides alike is by divine decree breaking the human chain of cause and effect, and so perhaps outside of earthly time. 
Such ultimate peace, indeed, is implied in all Greek drama. The Edipus at Colonus is set on the threshold of Athens, the violet-crowned city of God, shining white among its grey olives and its meadows of narcissus and golden crocus, and so radiant with an unearthly beauty of freedom and sinlessness that in the poet's thought it seems to be one with the spiritual city to which Edipus passes " without lamentation or sickness or suffering, a passing above mortal's wonderful."

This atmosphere was almost certainly the final one of all Greek tragedies or trilogies, but it has been overlooked and completely ignored by the Senecan writers who handed on the tragic tradition to the modern world. Why they made of it such a horrible thing will appear after further examination of the tragic heroes.

Aristotle's Poetics leaves a curious mummylike impression when one first reads it, or an effect as of a man of great intellectual power and culture using with awkwardness the language of an alien and primitive folk to express his ideas. He seems bewildered by fragments of shadowy traditions, old phrases, and haunting conventions which he cannot explain, and which yet guide his judgments like ghostly hands. Such is, perhaps, the explanation of the famous sentence about the Katharsis of 
tragedy: he knew that tragedy was in some way essentially a purgation, and he is trying to find a meaning in the phrase, just as other thinkers had tried to rationalize the primitive myths. Now, if we accept the theory of the origin of tragedy in the ritual of the Renouveau, it; becomes clear why Aristotle should have found. the word Katharsis associated with it. For pollution, both material and moral, must be cleansed before the rebirth could take place. And this cleansing was effected by the driving out or sacrifice of a scapegoat, who carried away sometimes into the world of the dead, sometimes into desert places, all the evils and sins of the old year. This pharmakos was normally someone of little or no personal value, a deformed person-someone, as one scholiast puts it, " conspired against by nature," probably often deficient mentally. But on great occasions the victim was not a malefactor or worthless, but someone specially "pure" and " perfect" - the King himself, or a virgin of royal birth. The romantic interest of such figures would be very great indeed, and my suggestion is that the essence of tragedy is just this figure of the pharmakos, or scapegoat, one round which an appalling cloud of guilt hangs and who is yet morally innocent. It explains the common instinct that the tragic hero must 


\section{PHARMAKOS AND DIVINE KING 59}

neither be innocent nor guilty, but must be overwhelmed by a tremendous catastrophe which we yet feel to be a natural consummation of his action. On the other hand, the pharmakos was usually treated with royal and even divine honours for a short time before his sacrifice, and the evidence goes to show that this was because there was some confusion or deliberate identification of the scapegoat with the primitive divine King who was slain and reborn every year. Thus there grew up in the Greek mind the connection between terrible unmerited isolation and suffering, and divinity, and perhaps in the lower types, of enormous guilt with divinity, for that is the form in which it appears in Senecan plays. If the Greek dramatists can be held at all responsible for this degenerate conception, the blame must probably be laid at the door of Sophocles, and a short examination of the seven extant tragedies will suggest how it came about.

The other two dramatists had seen in their hero or heroine something of the scapegoata human creature who suffered for the sins of others-and they were attracted by the interest of the personality which this intense light of injustice and martyrdom tended to throw into relief. But Sophocles in this, as in other respects, moves deliberately in a somewhat more 
archaic atmosphere. He seems to be attracted by the study of religious psychology from two connected points of view : (1) He is interested in the movements of the more or less orthodox-really very primitive-mind under the pressure of religious dogma and of superstition; and (2) he accepts and is interested in the scapegoat, not as victim, but as developing divinity. He steeps himself, apparently, in the conception of the divine Scapegoat King, the polluted and outcast one, who is after all identical with him who is reborn in glory. He watches this scapegoat, becoming in some sense a god, and analyzes the sensations he experiences. If the drama had become by this time, as seems fairly certain, a religious and moral exercise, designed to purge or elevate the audience sympathetically, the poet must have had the double task before him of exhibiting the phases of the apotheosis and at the same time effecting a somewhat similar process in his auditors till they, too, were rapt into infinity. This, at least, is what I take to have been Sophocles' conception of his task. From the scapegoat tradition he gets the idea of a connection between divinity and something shameful-unnatural crime and loathsome disease-even the idea that such shame is a necessary element. His heroes are all hagioi- 
taboo-hagos is in fact for him the essential quality of a tragic hero. Edipus is the culminating example, and must be examined at length. We will take the others first.

The Trachinia, with its anticipations of the passing of Arthur, has for hero a manifest and acknowledged example of the man-god. He must pass mysteriously lest he die of disease, and the world with him. Heracles has just that haunting quality of sin about him which is the distinguishing mark of the scapegoat, and, moreover, he has taken on him the burdens of all men. The full meaning of the play only comes out in connection with the Philoctetes. Philoctetes is the true heir of Heracles, for when his son Hyllus refused to light the funeral pyre on which the tortured but still living demigod was laid, Philoctetes did the deed, and so, taking the son's place, he inherits at once the mysterious power with its symbol, the bow, and also the mysterious curse and shame. It is characteristic of Sophocles to dwell on the noisome disease from which he suffers, and to make us feel that it is inextricably bound up with his magical power. The play ends with a theophany of Heracles, who announces that he has won immortal rank, and through this travail Philoctetes, too, shall attain glorious life. 
Antigone is another clear example. She bears the sins of her house. "Thou art paying haply for thy father's sin" (856), the chorus suggests, and Antigone shrinks from the voicing of her chief terror-she is afraid of that terrific burden. By a purely symbolical act she incurs guilt, and she passes still alive to Hades "as no other of mortal kind has passed." The superstitious hypocrisy of Creon, which holds that he does not know whethe: she will live or die when once immured in the rocky tomb, finds in his victim a terrified belief. "I will take her where the path is loneliest, and hide her living in a rocky vault with so much food set forth as piety prescribes, that the city may avoid a public stain. And there, prayings to Hades, the only god whom she worships, perchance she will obtain release from death" (773 ff.).

Antigone herself says that she has no homo: in the earth or in the shades, no home with tho living or with the dead (850). When tho chorus likens her fate to that of gods she crie:s out in agony. It is not merely the ghastly mockery of the pretence that for her some unique or unhuman life may be found, the terror lies in the possibility that it may be true.

The Ajax falls very simply into the samo category. The play is based on the ritual of 
the festival Aianteia, in which the dead Ajax was accepted as a hero (i.e., as an object of worship), and was carried through the streets on a bier with his armour piled beside him. The feast was meant to commemorate the victory of Salamis, which accounts for the irrelevant chorus about Salamis. It seems likely that the play ended in a burial procession like that of the feast, and Ajax has in any case clearly attained the status of hero, or daimon. In the process of attaining it he has been mad, done shameful deeds, and at last committed suicide. Hence he is "hagios," all the more so perhaps that the gods have fooled him and frustrated his superhuman vengeance. One does not, however, feel the special divine atmosphere about Ajax so strongly as about Edipus or Heracles.

But the most important of all is certainly Edipus. He had challenged the gods by his

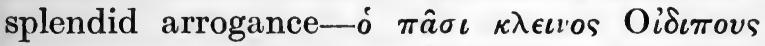
$\kappa a \lambda \circ v \dot{\mu} \mu \nu \circ \varsigma$-and by proclaiming it his function to discover and purge the sins of his people. He claims, in effect, the office of scapegoat. "I bear the anguish of these rather than that which is the portion of my own soul" (I. 93, 94); and again: "My soul groans for the city and for thee, as well as for myself." 
At the same time he is intrinsically a polluted thing, stained with crimes too horrible to name-" the pest, the most accursed, the most god-hated of mortals." Creon rebukes the blind King's attendants for allowing his presence to taint the sunlight. "Ye, if ye respect the children of men no more, revere at least the all-nurturing flame of our lord the sun, spare to show thus nakedly a pollution such as this - one which neither earth can welcome, nor the holy rain, nor the light." (1424 ff.).

Legend denies to Edipus the swift death which modern readers feel to be the natural close of CEdipus the King; is it too bold to say because as a scapegoat he must be driven out and wander? Edipus had himself asked Creon, the messenger to Apollo, with what "purgation" the land was to be freed from stain, and the answer is emphatic: "By driving out a man." The word used comes from the name applied to the "avenger of blood," and the action is that of this avenger. Creon goes on immediately to say that it is on account of this stain that the winter is on the city-

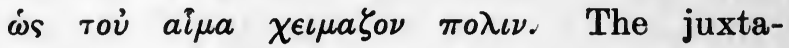
position of the three ideas of purgation, a venging of blood, and winter is at least curious, and in view of Sophocles' tendency to a sort 
of mosaic work of suggestion in his language can scarcely be without significance.

CEdipus is then accursed, polluted by involuntary but hideous sin. And the nature of this sin seems to put him outside the pale of humanity, so that he feels himself utterly alone, a unique horror, hagios-charged, that is, with a sort of spiritual electricity or magical power. The unwillingness to touch him at the end of the Turannos makes this quite clear, and the Edipus at Colonus is merely a long elaboration of the fact. It is, perhaps, the only Greek play which makes a definite effort to produce the feeling of the extra-natural in this sense. It is as if the meaning of CEdipus' final exit in the Turannos had been obscured by the previous horror, and Sophocles had written the Colonoeus to emphasize the divine side of the tragic hero. The eagerness of the claimants for his body as well as the divine voice, paralleled only in the Baccho, all seem to show the motif of the play.

Further, it is the peculiarity of the tragic hero that it is his body which has a magical quality, and in CEdipus we see why. $\mathrm{He}$ is an unnatural birth, a monstrosity, without a single clean physical relationship, and therefore, as it seems to the logic of the primitive mind, he must be born of the supernatural. 


\section{SOPHOCLES AND SENECAN PLAYS}

The supernatural quality in Shakespeare's Richard III. is due to the same unnatural physical conditions cutting him off from the great bond of human society, and yet leaving him non-spiritual:

"I have no brothers, I am like no brother;

And this word 'love,' which greybeards call divine,

Be resident in men like one another

And not in me: I am myself alone."1

This is at least one stream of thought which tends to select the scapegoat from among those " conspired against by Nature," a deformed person or a fool; while, on the other hand, monstrous and unnatural, though involuntary crime tended to become one of the conditions of apotheosis. It led on, therefore, to Seneca's fiendish monsters of tragic heroes, and it was with this Sophoclean conception in his mind that the Senecan dramatist treated the Orestes story.

1 It has been noticed, I think, that the circumstances of Richard's birth are much the same as those of Merlin in the absurd but popular play of The Birth of Merlin, and are thus taken as proofs that Merlin's origin is a " mixture of infernal seed ":

" That thus 'gainst nature and our common births He comes thus furnish't to salute the world, Is power of Fates, and gift of his great father" (i.e., the devil). 
For the pre-Shakespearean avenger Ægisthus was directly and indirectly more important than Orestes himself-Egisthus, with his duplicate or shadow, Atreus. Now there always hangs over the character of Egisthus a half-expressed question: "Was he or was he not a coward ?" and on the whole the answer goes against him. In Æschylus he leaves Clytemnestra alone to kill Agamemnon, though the legend seems to have varied on this point. In Seneca he is not so much a coward as a cad. He hounds on Clytemnestra, closing to her the way of possible reconciliation with her husband to save himself. Clytemnestra throws his incestuous origin in his face, and has a moment of repulsion when she feels that Agamemnon is, as we should say, at least a gentleman, and that this man is not. If he had been the true royal-natured Turannos he would have done his own slaying, and taken the Queen in the usual manner. But Egisthus is not true-born, and he has not the royal resentment, the royal way of avenging without fear of consequences. We see the other side of the same thing in Seneca's Atreus. Atreus, about to perpetrate a fiendish vengeance, is afraid lest his resolution should break down; he is not, perhaps, a great enough man for this superhuman deed. He lashes himself up by remembrance of his wrongs : 
" O slothful, indolent, weak, unavenged (This last I deem for tyrants' greatest sin In great affairs), after so many crimes, After thy brother's treachery to thee, Dost thou, $O$ angry Atreus, waste the time In idle lamentations All the world Should echo with the uproar of thy arms," etc.

"Waste the time in idle lamentations, unpack my heart with words" (Hamlet). "While I threat he lives; words to the heat of deeds too cold breath gives" (Macbeth). The idea at the back is the same: the royal and divine mania, or mana, descends on the hero like an inspiration, enabling him to perform superhuman actions. Atreus afterwards exults to feel it descending on him:

"I know not what great passion in my heart, Wilder than I have known, beyond the bounds Of human nature, rises, urges on My slothful hands."

\section{SeCtion II}

THE PRE-SHAKESPEAREAN AND SHAKESPEAREAN TRAGIC HERO TO THE EARLIEST HAMLET. SIIAKESPEARE'S REJECTION OF THE SUPERMAN

When we turn to Elizabethan drama we find that in various groupings and by devious ways most of the associations of the Greek tragic hero have reached the modern world. They 
are conventionally and imperfectly covered by the word "honour." In Marlowe's work the coneeption is clear that he must be one who claims equality with the gods:

"Come, let us march against the powers of Heaven, And set black streamers in the firmament To signify the slaughter of the Gods,"

cries Tamburlaine. Tragedy lies simply in the fact that this hubris, this spirit "lift upward and divine," is tied to flesh, and must therefore be subdued in the end. Marlowe has no hint of tragic error: simply the greater the vitality, the spirit of the man, the more fiercely he will rebel, the more monstrous does his mortality appear. The poet's art lies wholly in his power to picture the intensity of life, and therefore of death. It is the essential nature of man laid bare. But because of the long tradition behind him, Marlowe expressed this infinite vitality by unbridled cruelty and wholesale crime:

"Nor am I made arch-monarch of the world For deeds of bounty and nobility;

But since I exercise a greater name, The scourge of God, and terror of the world, I must apply myself to fit those terms.

In war, in death, in blood, in cruelty, And plague such peasants as resist in me The power of Heaven's eternal majesty." 


\section{HONOUR AND THE DIVINE MANIA}

It is, in fact, the doctrine of the superman long before Nietzsche, but it has clearly links with Aristotle's " magnanimous man," and the word "honour" is used or implied from this time on as the subject of all tragedy.

In Kyd's Spanish Tragedy we find a far less perfect work of art, but a much more complex and perhaps fruitful conception. The title and subject suggest a Spanish source, and it is worth noting that the view of honour and of its satisfaction seems to be specially Spanish; and when we examine this idea of honour we find strong evidence for identifying it with that quality in Edipus which made him claim the part of a god, with the spirit which descended on Seneca's Atreus, the passion beyond the bounds of human nature which urged him to avenge with deeds of horror the attempt to deprive him of his kingdom and sedue ;his wife. On this side such deeds are an expression of the avenger's virile and superhuman energy. But there seems to be another element going back also into primitive, even savage, conceptions. A dishonour seems to be an invasion of the personality-the vital essence of the person is soiled and weakened. According to the Spanish conception, this dishonour could only be wiped out by your enemy's blood.

The source of Corneille's Cid is certainly 
Spanish, and the story of the first duel is very interesting in this connection. Don Gomès has objected to Don Diègue being made Governor to the heir apparent on the ground that, being old, he will not imbue the Prince with the proper courageous spirit. Now, logically, the only proper refutation of this insult should have been for Don Diègue himself to challenge his enemy. But apparently it was essential not merely to show courage, but actually to shed the insulter's blood, for the old man insists that his son shall represent him in the duel. This suggests two lines of tradition, the first being the solidarity of the family. Their virility, cqurage, honour is one and indivisible, /and if impugned in any member it is impugned as a whole; on the other hand, the courage and vigour of y member reflects glory on all, and proves the. family's vitality. The second is suggested by savage analogies in far-off times. Was the weakened vitality of the insulted family perhaps reinforced by the drinking of the enemy's blood, as, for instance, that of the child Julio in Marston's Antonio's Revenge? That hero says: "I'll suck red vengeance out of Piero's wounds "; and Hamlet, on his way to his mother's bedchamber, tells us: "Now could I drink hot blood."

It is difficult to be sure how far these savage 


\section{HONOUR AND THE DIVINE MANIA}

traits were present to Kyd's mind when he wrote his play, and how far they had been partially devitalized into mere unreasoned conventions, but Kyd introduced a new and really fine element by making his avenger a very old man. That Hieronimo is very old is, I think, quite certain. I incline to suspect that his creator even allowed him to be a little ridiculous, as Polonius is ridiculous. $\mathrm{He}$ is so in the first part of Hieronimo, and even if Professor Boas is right in thinking that Hieronimo is a later production by another hand, the fact that it was acted at the same theatre as the Spanish Tragedy and about the same time implies that the two representations of $\mathrm{Hie}$ ronimo did not clash. If an audience had been allowed to laugh one night every time the old man appeared, they could not be expected to feel the same character wholly dignified a day or two later.

We may take it, then, that Hieronimo is very old and a little ridiculous in his devotion to his son. The appeal of the play was the spectacle of this half-doting old man trying to perform the duty of avenging the honour of his family. He fumbles ineffectively for some time. It is certainly a mistake to suppose that Shakespeare's Hamlet introduced the idea of hesitation on the part of the avenger. In 
one place an old man comes to Hieronimo to demand justice from him as Marshall for the murder of a son. Hieronimo is on the verge of madness, but after a little confusion he realizes that the old man's position is the same as his own. He speaks to himself lines which should be compared with Hamlet's on the player's passion:

"See, see, ah see thy shame, Hieronimo,

See here a loving father to his son;

Behold the sorrows and the sad laments

That he delivereth for his son's decease.

If love's effects so strives in lesser things,

If love enforce such moods in meaner wits,

If love express such power in poor estates. . .

Then shamest thou not, Hieronimo, to neglect

The sweet revenge of thy Horatio ?"

The thought here is still linked with that of the Senecan hero: the noble man is still he who resents greatly and avenges by shedding rivers of blood, passion is still regarded as a desirable state to be attained by an hysterical process of self-excitation; but because it is his old age that makes Hieronimo's sorrow at once womanish and intermittent, the piteousness of mortality has given the play an element of great art-it is "brackish with the salt of bitter tears."

It was at this stage that Shakespeare began to deal with the subject, and it may be suggested 


\section{HONOUR AND THE DIVINE MANIA}

that the two periods of popularity of Kyd's play severally produced in Shakespeare two trains of thought-that of Hamlet and that of King Lear. It is at least remarkable that the so-called Ben Jonson additions for the revival of the Spanish Tragedy were to the madness of Hieronimo, and that the most prominent stage feature of King Lear must have been Lear's madness. The Lear of the older play on which Shakespeare founded is not mad, and, moreover, the madness of Lear fills the third act just where Shakespeare, with that instinct for the practical details of his art which is so often a gift of his great genius, generally places those incidents and scenes calculated to give the most intense excitement. This suggests that, as a piece of stage-craft, the play was written round the madness of Lear, and Shakespeare knew the madness of an old man would thrill his audience with attention because of the contemporary success of "Hieronimo is mad gain."

If we turn back to Hamlet we find a general agreement that Shakespeare is indebted to the old play to a certain extent. The resemblance between the plots is obvious. In both cases you have in the earlier part plans for securing vengeance for a death before the play opens. 
In both there is a war in the background, both $\checkmark$ have a ghost demanding vengeance. Then about the middle of the play a fresh murder is committed, a new avenger comes on the scene-Hieronimo in one case, Laertes in the other. It is true that in Kyd's play the second avenger is the real hero, while Laertes is a very slight figure; but if we examine the play we shall see that the unity of interest in Hamlet has obscured the fact that Shakespeare's drama is as loosely constructed as that of Kyd. Laertes appears twice in the first part of the play, both times awkwardly, and a scene is introduced for the express purpose of reminding us of his existence; in the second half he is constantly on the stage, and a prominent figure in all the exciting scenes. Hamlet, on the other hand, is constantly on the stage in the first half of the play, while in the second half, especially in the first quarto, he is kept in mind until the final catastrophe by devices similar to those employed in the first half in the case of Laertes.

Where did this curious reduplication of the plot come from?

It does not strike us very forcibly in reading the Greek dramas on the subject of the Atridæ that the story is repeated several times over, situation and character being re-echoed, as it 


\section{HONOUR AND THE DIVINE MANIA}

were, in the different generations. Such is, however, the case to a great extent, and it was emphasized with magnificent effect by Eschylus in his choruses. It symbolizes the eternity of sin, and is the theory at the back of a certain kind of ghost-story that some actions are so intense that they reverberate again and again till the emotions which gave them birth are exhausted. Possibly, in consequence of the Agamemnon chorus, the idea of this redupli.cation as the groundwork of tragedy became; impressed on the authors of the plays passing; under the name of Seneca, and through Senecan. drama it became a fixed tradition in this type of Elizabethan tragedy. In Seneca Atreus. avenges himself on his brother Thyestes because he has seduced his wife and tried to drive him from their joint kingdom. His vengeance takes the form of murdering Thyestes' sons, and serving their bodies as food to their father. Egisthus, the illegitimate son of Thyestes; slays Agamemnon, son of Atreus, and weds his wife. Orestes slays Agisthus. You thus have three murderers, and each avenging a seduction and the loss of a kingdom, and occasionally they seem to be identified or confused. If they represent in origin, as is probable, the priest-king, "who slew the slayer and shall himself be slain," it is easy to under- 
stand that they are at once the same and different.

The so-called Senecan plays include a Thyestes and an Agamemnon, and in them the avenger view of Egisthus is somewhat emphasized. As a result, in each Elizabethan drama (or pair of dramas in earlier times) we tend to have two important murders and two avengers -an older and a younger man, for the most part -and the characteristics of the avenger type are distributed between them. Roughly, Atreus and Egisthus are represented by the older man, and Orestes by the younger; but this classification does not hold always. In Hamlet, where there are two avengers, both young, nearly all the qualities of the Greek tradition are heaped on Hamlet, and Laertes becomes a rather uninteresting figure in consequence. In Marston's Antonio's Revenge, however, the two types are kept distinct: Piero, the older man, corresponds to AtreusAgisthus, Antonio, the younger, to Orestes. Piero, who is a sort of anticipation of the Byronic hero, has lost the woman he loved (and still loves) to Antonio's father. $\mathrm{He}$ is embittered, energetic, resourceful, and quite unscrupulous - for example, he gets rid of an inconvenient accomplice by a peculiarly shocking example of the confidence trick. At the 


\section{HONOUR AND THE DIVINE MANIA}

same time, he is still devoted to Antonio's mother and to his own little son, and it is through them that he meets his doom. The appeal of Antonio is his youth and accumulated misfortunes. It is possible that the appeal of the first Hamlet was something the same, that the interest lay in the overwhelming vengeancis achieved by a very young Prince with every external circumstance against him Shakespeare has taken trouble to mark the mature age of the final Hamlet, and done so at the expense of introducing inconsistencies into the plot. If Hamlet were thirty years of age wher his father died, perfect in person, of great, intelligence, a skilful soldier, only remarkable, unpopularity could possibly have led to his being passed over for the crown. But Hamlet is so popular that when he has committed a shocking murder Claudius dare not have him punished in Denmark. It seems evident that Shakespeare, to get his psychological truth, has sacrificed external probability, but that the first Hamlet was young. If so, just as in the Spanish Tragedy, the delay would be due simply to the difficulty of the enterprise, the strength of Hamlet's enemies, and the weakness of his youth. The motive of the play is the same-the exhibition, in one whose physical weakness might be expected to preclude such 


\section{REDUPLICATION IN “MACBETH” 79}

a quality, of a superhuman energy, a divine madness, an exalted sense of his own and his family's honour giving sufficient impetus to carry him over all difficulties. That the im-pediment is immaturity might have made the play less immediately interesting than the Spanish Tragedy, and the comparative neglect of the "wiser sort" during the earlier stages of its history may have been justified, or at least natural.

The same sort of reduplicated revenge plot can be traced dimly in Macbeth, a play which in a cruder form may have been Shakespeare's first. If this were so, Macbeth would be the elder, Malcolm the younger, avenger. Kempe, the comic actor, in a pamphlet published in April, 1600, speaks of a "ballad" whose author was found at the Globe Theatre. He was " a proper upright youth, only for a little stooping in the shoulders, all Hart to the heel, a penny poet, whose first making was the miserable stolen story of Macdo-el, or Macdo-beth, or Mac Somewhat, for I am sure a Mac it was, though I had never the maw to see it." An "upright man" was the technical name for a sturdy beggar or thief, and Kempe is therefore hinting that the "penny poet" was indebted to others. The "stooping in the shoulders," it has been suggested, points 


\section{HONOUR AND THE DIVINE MANIA}

at Shakespeare, whose part of Richard Crookback had been a success on the stage, and seems to have been performed by the poet himself. "All Hart to the heel" may be an allusion to the obvious imitation of $\mathrm{Kyd}$ in these early revenge plays. But the important point is the punning allusion to Langland's " Do wel, do bet, do best," in the title of the, " miserable stolen story." Even an Eliza. bethan punster would have had difficulty ir making his point with a play called simply Macbeth. It is difficult to see how the connection could occur to him. But there is a Scottish patronymic pronounced exactly Macdo-el, although written Macdowell, and in Holinshed's story the rebel whom Macbeth subdues is called Macdowald, not, as in Shake. speare, Macdonwald. The dropping of the final " $d$ " is common, and thus we get a name which would easily suggest Kempe's pun. In Shakespeare Macdonwald is unimportant, and neve:: comes on the stage, so that a man who had neither seen nor read the play would be mos; unlikely to know of his existence. Kempe'is pun therefore suggests that in this old play Macdowald was a person of almost equal importance with Macbeth, and his story is just of the kind to appeal to a dramatist of this Senecan type. When Macbeth took his castlo 
Macdowald set fire to it, and died with his wife and children in the flames. Conjecture is very tempting, but a few points only can be noted. In Shakespeare's play the part assigned to Macduff is of inconsequent importance. We expect Malcolm to kill Macbeth. Further, the sudden introduction of Lady Macduff and her son merely that they may be killed is quite inartistic. Again, the question of Malcolm forces itself on our minds, "Why in that rawness left you wife and child?" "Why did Macduff leave his family to the mercy of the tyrant?" and the play gives no answer.

Now, if there was a play on this subject as early as 1600, the whole story of Banquo must almost certainly have been omitted. Queen Elizabeth did not permit speculations as to her successor, and the scene of the vision of Banquo's descendants is, besides, of a late fashion. If, then, Banquo is eliminated, it seems possible that his place as Macbeth's "partner" in subduing the rebel may have been taken by Macduff. In that case, the massacre of Macduff's wife and children would be a parallel to the earlier massacre of Macdowald's family, and there is an added meaning in the bereaved father's remorse: 


\section{HONOUR AND THE DIVINE MANIA}

\section{"Sinful Macduff,}

They were all struck for thee! naught that I am, Not for their own demerits, but for mine, Fell slaughter on their souls."

Macduff may have suspected Macbeth of seducing his wife, and fled on that account. Such a supposition would make the play much nearer to type, and would make more intelligible the curious conversation between Lady Macduff and her son. It would give grounds for calling Macbeth "luxurious," taking him as a type of "lust" and voluptuousness only to be outstripped by Malcolm's mythical vices. That was, of course, one of the regular traits of the murderer in these stories, and its sudden appearance in Macbeth's case in the second part of the play, and without a single incident to suggest or explain it: is one of the many proofs of the superimposing of one dramatic conception over the other. However that may be, a comparison of Shakespeare's play as it stands with Marston's Antonio's Revenge, already referred to, brings out the close resemblance of the two plays and the probability, amounting almost to certainty, that Macbeth himself is Shakespeare's version of the elder avenger type. Marston's play is earlier than our Macbeth.

If Antonio's Revenge were ever acted in modern 
times, the likeness of its opening scenes (Act I., Scenes 1, 4, and 5) to those in Macbeth, Act II., could not have been overlooked. Piero's first entry, " unbraced" and carrying in one hand a bloody dagger, in the other a torch, is very like the scene where Macbeth is on his way to the murder carrying a torch and a dagger on "whose blade and dudgeon" the "gouts of blood" are yet fantastical. Each has an attendant with him whom he dismisses, soliloquizing in something the same strain. Macbeth says:

"Now o'er the one half world

Nature seems dead, and wicked dreams abuse

The curtain'd sleep; witchcraft celebrates

Pale Hecate's offerings, and wither'd murder, Alarum'd by his sentinel, the wolf,

Whose howl's his watch, thus with his stealthy pace, With Tarquin's ravishing strides, towards his design Moves like a ghost. Thou sure and firm-set earth, Hear not my steps, which way they walk, for fear Thy very stones prate of my whereabouts, And take the present horror from the time, Which now suits with it. . . ."

[A bell rings.

Piero says:

“"'Tis yet dead night, yet all the earth is clutcht In the dull leaden hand of snoring sleepe. No breath disturbs the quiet of the ayre, No spirit moves upon the breast of earth, Save howling dogs, night crows, and screeching owls, Save meagre ghosts, Piero, and black thoughts. One, two!" 


\section{HONOUR AND THE DIVINE MANIA}

The last words refer to the strokes of a bell, for he continues:

"Lord, in two hours what a topless mount

Of unpeer'd mischiefe have these hands cast up."

The stage directions in Macbeth at this point do not indicate how often the bell rings, but in the sleep-walking scene Lady Macbeth counts, as Piero does here, and she also counts two.

Anyone who turns to Marston from Shakesspeare will be struck by the younger poet's shortness of breath. He seems incapable of sustaining his flight. A certain amount may be due to the extreme corruption of the texts, but the defect is clearly characteristic; when we get parallel passages like those above from the two dramatists we see the difference at once. Examination suggests that magnificent paraphrase is the best description of Shakespeare's work in these cases, and it should be noted that this elaborating process does not consist merely in giving greater sweep to single speeches, but in prolonging, repeating, and sustaining hints in the drama which we call the source. In this particular case, for the one entry of Piero carrying dagger and torch with the attendant we have in Shakespeare's play Macbeth's entry with an attendant bearing a torch; then the interlude of the conversation 
MACBETH THE ELDER AVENGER 85

with Banquo; then Macbeth's soliloquy, having dismissed the attendant, and finally his re-entry after the murder of Duncan. The same kind of elaboration is evident in the second quarto of Hamlet.

To return to the Macbeth series. In both Shakespeare's and Marston's plays the retirement of the murderers to bed is followed by scenes with a comic element and accounts of portents in the heavens. And then, again, we have stage situations which, if represented in dumb show, could not be distinguished. In each play a courtier enters announcing that he has found a Sovereign murdered. In both the only woman present faints, and is assisted out. In both the villain "gives seeming passion," and in both he acknowledges having killed, as he says, in a fit of indignation someone who might have been inconvenient. In both real mourners, being left alone together on the stage, condemn the violent expression of emotion. There is also a fairly close parallel between the speeches of Piero and of Macbeth. Piero :

"There glows no sparks of reason in the world; All are rap't up in arctic beastliness. The bulk of man's as dark as Erebus, No branch of reason's light hangs in his trunk: There lives no reason to keep league with all. I ha' no reason to be reasonable." 


\section{6}

HONOUR AND THE DIVINE MANIA

And Macbeth :

"Renown and grace is dead;

The wine of life is drawn, and the mere lees

Is left this vault to brag of."

But if Macbeth is Shakespeare's treatment of the elder avenger, we have a definite pronouncement against the megalomaniac. Marston's Piero-the direct heir of the Senecan Atreus-had expressed it fully:

"Lord, in two houres what a toplesse mount Of unpeer'd mischief have these hands cast up. I can scarce coop triumphing vengeance up From bursting forth in braggart passion. Andrugio sleeps in peace; this brain hath chokt The organ of his heart. Feliche hangs

But as a baite upon the line of death To 'tice on mischief. I am great in blood, Unequal'd in revenge. You horrid scouts That centinel swart night, give loud applause From your large palms."

These words are spoken by Piero in that opening scene of the second part of Antonio and Mellida which we have noticed is in many respects so like the murder scene in Macbeth. Macbeth, too, remembers that his victim " sleeps well," but it does not come to him as a thought of triumph, but with the yearning envy of one who himself " shall sleep no more." For Piero's " horrid scouts that sentinel swart night, and give applause from their large palms," Shakespeare makes Macbeth see Dun- 
can's virtues like angels and cherubin riding upon the wind and trumpeting his crime to the world; and when Lady Macbeth taunts him with cowardice because he lets "I dare not wait upon I would," he answers in words that seem almost like the personal declaration of his creator: "I dare do all that may become a man; who dares do more is none."

The germ of this megalomania, I believe, Shakespeare found in the Stoic doctrine of self realization, and he treats the subject in Julius Coesar and again in Coriolanus. Brutus remains faithful to his creed, and a moral tragedy is the result. Coriolanus at first follows the same course, demanding:

"Would you have me

False to my nature? Rather say I play

The man I am."

But in the end he tacitly negatives Volumnia's question:

"Thinkest thou it honourable for a noble man

Still to remember wrongs ?"

and takes on him the part of peacemaker, knowing that his own death will be the price:

" O my mother, mother ! 0 !

You have won a happy victory to Rome;

But, for your son, believe it, $\mathrm{O}$ ! believe it, Most dangerously you have with him prevail'd, If not most mortal to him." 
The character of Brutus generally attracts much more sympathy, but it is doubtful whether Shakespeare ever appreciated the Republican ideal on which its nobility rests. That even a benevolent despotism might be intolerable to a free people seems scarcely to have been understood by him. Genius in every age and country instinctively turns to the philosophic absolute ruler. Brutus is a very pure and noble nature, but his first concern is to realize his ideal self, and this ideal self in its political aspect of the perfect patriot included the liberator of his country. His name and descent suggested it, Cassius kept harping on it, and so he was a little too ready to find a tyrant whose removal would consummate his own development. The soliloquy, "It must be by his death," is curiously like Macbeth's, "If it were done, when 'tis done." Both admit that their intended victims have been clear in their great office, both lack any spur to action save their own ambitionin Macbeth's case the coarser natural ambition of a crown, in Brutus the more insidious but far nobler ambition of realizing his ideal. The funeral oration of Antony, which forms the pivot of the play, thrusts home Shakespeare's conception. Brutus was honourable we realize, but as Antony proceeds, returning again and 
again to the word, we begin to see what this honour means. The quarrel with Cassius reveals a weakening of Brutus' moral sense as a result of his earlier paltering with his ethical instincts. He storms at Cassius for refusing him the gold he is too honourable to collect by vile means, but not too honourable to receive, and he accepts with complacency the admiration of Messina for his stoical reception of the first news of his wife's death, though he had already offered his loss to Cassius as an excuse for his irritability. It is part of the tragedy that his cause is lost, because Cassius loves him too dearly to risk a second quarrel by insisting on his mistake in generalship; but morally Brutus is saved just by his capacity for giving and arousing love, and by his consciousness not merely of his own nobility, but of that of those about him:

"My heart doth joy that yet, in all my life, I found no man but he was true to me."

The Senecan superman is solitary, self-sustained, incapable of appreciating others, a unit in an alien universe; to Shakespeare greatness and egotism never go together, and his heroes " live along" every thread of human connection. It is worth noting that in Plutarch's life Coriolanus only marries to please his mother, 
and it is implied that his wife meant nothing to him; but none of Shakespeare's heroes addresses the woman he loves so tenderly as Coriolanus "his gracious silence."

\section{Section III}

A DIGRESSION TO SUGGEST THE WAY IN WHICH POST-SHAKESPEAREAN TRAGEDY IS STILL OCCUPIED WITH THE SAME CONCEPTION IN A NARROWER FORM

The contention that this question of honour was the central one of Elizabethan tragedy may be supported by a rapid sketch of postShakespearean drama showing how it links all in a coherent system. There is a tendency to take women's honour as the main subject, for which several reasons may be offered.

In the first place, the dramatists clearly felt the comprehensiveness of Shakespeare's genius, and realized that where he had reaped their gleanings must be scanty. But Shakespeare's delineation of women is almost entirely from the external point of view. We know Ophelia, Imogen, Cordelia, as we know our intimate friends, perhaps as a man knows the woman he loves, but not as we know ourselves. Nor does Shakespeare, with one exception, ever give a 
full-length portrait of a woman. The exception is perhaps significant, for it is Cleopatra, and when she cries out in scorn of the idea that " some squeaking Cleopatra" may "boy her greatness" we realize that, however inadequate a representation a boy-actor might give of the great courtezan, it would not be fundamentally false as his direct representation of Cordelia would be. In the later plays the women's characters are suggested mostly through the feelings and words of others: Lear, Kent, the Fool, give us the real Cordelia; her brothers, Posthumus, Pisanio, Imogen as she lived and breathed; Emilia and the courtiers Hermione and Perdita.

Here, then, was ground which Beaumont and Fletcher and their later contemporaries, writing with the possibility that their creations would be interpreted by women, might make their own.

There may have been another more interesting reason. A man's honour by the seventeenth century is to a great extent a thing of conventions, and few of the dramatists attempt any real analysis. But a woman's honour is of the very essence of her being, and questions concerning it can never be of a passing fashion. By laying most of their emphasis on this subject the Jacobite dramatists built their creations on the everlasting rock of human nature. The 


\section{POST-SHAKESPEAREAN TRAGEDY}

effect may be seen in two of Beaumont and Fletcher's plays: The Maid's Tragedy and Bonduca.

The men in The Maid's Tragedy are unreal enough. It is difficult to take any interest in Amintor's problem of the conflict between his loyalty to the King and his honour as a man. Melantius, apparently, is the same sort of foil to him that Laertes is to Hamlet. But Evadne gives unity and life to the play. She seems to have been of a type the twin dramatists understood. Originally fiercely virgin, she had become the King's mistress because she regarded it as something less sensual-more abstract, as it were-than to be the wife of a subject. She tells the King frankly that she will only be faithful to him while he is a King. Something in Melantius' words makes her suddenly realize that she is a corrupt thing. He tells her-

"Thou hast death about thee:

He has undone thine honour, poisoned thy virtue, And, of a lovely rose, left thee a canker."

And when she comes to kill her seducer her horror of herself is expressed in the same phrase:

"I am as foul as thou art. . . . I was once fair, Once I was lovely; not a blowing rose More chastely sweet, till thou, thou, thou, foul canker, (Stir not) didst poison me." 
She thinks that when he is dead she will be pure again, and when she realizes that in Amintor's eyes her crime has only added to her degradation her tragedy is complete.

Bonduca treats the theme of honour in every possible variation. We have the typical honourable man in Caratach, while the child Hengo gives a pathetic touch. The Roman officer Pœnius, whose high spirit resents the form of the order to advance, and so lays himself open to the imputation of cowardice, kills himself at the thought of the dishonour. Petillius, who had encouraged him to the deed, being himself degraded, desires also to commit suicide, and is saved only by a fricndly trick, which persuades him that what he had looked on as an indignity is really a special opportunity for glory. The pulse of life is seen again in the women. When escape is found to be impossible, Bonduca orders the means of self-destruction to be brought to herself and her daughters. The younger one hesitates, but when her sister reminds her that in death alone she will be safe from the lust of her captors she exclaims, "That steels me," and stabs herself.

Ford's Broken Heart is interesting, because the prime mover of the tragedy, Orgilus (the name has some significance), is of the regular Senecan temper, and the dramatist appears 


\section{POST-SHAKESPEAREAN TRAGEDY}

to denounce explicitly the ethical standard involved:

"But know then, Orgilus, what honour is:

Honour consists not in a bare opinion, By doing any act that feeds content,

Brave in appearance, 'cause we think it brave;

Such honour comes by accident, not nature,

Proceeding from the vices of our passion

Which makes our reason drunk: but real honour

Is the reward of virtue, and acquired

By justice, or by valour which for basis

Hath justice to uphold it. He then fails

In honour who for lucre or revenge

Commits thefts, murders, treason, and adulteries."

The play contains, too, an attitude to women's honour which reminds one of Shelley. Penthea, married to a man she cannot love, goes mad with the sense of pollution:

" O my wretched honour! ruined by those tyrants,

A cruel brother and a desperate dotage.

There is no peace left for a ravished wife

Widowed by lawless marriage."

Greatly inferior to Ford in every way, Massinger's treatment of honour is a return to the individualism of pre-Shakespearean writers. His asceticism is of the kind that shows a thoroughly corrupt mind. All human affections appear to him as degrading, and his ideal woman, Camiola, proves her honour by becoming a nun : 
"She well deserves

Her name, the Maid of Honour! May she stand To all posterity a fair example

For noble maids to imitate. . . . There being nothing Upon this stage of life to be commended, Though well begun, till it be fully ended."

Webster might almost have written for the purpose of refuting Massinger's slander of human nature. In Painter's Palace of Pleasure, from which the story comes, the Duchess of Malfi is treated as having betrayed a sensual nature by her marriage with a man of such inferior rank-just the sort of attitude of Massinger in all such questions. But Webster's Duchess is a noble human being, who manifests her completeness by her warm human passions and yet retains her royal fortitude under diabolic tortures. Her death scene is pure and sweet, with the homely directions about her children:

“I pray thee, look thou giv'st my little boy Some syrup for his cold, and let the girl Say her prayers ere she sleep."

But in spite of the long-drawn-out tortures of her mind she is "Duchess of Malfi still," and goes to her death with a dignity and a smiling self-possession thrown into vivid contrast by her faithful maid's abject entreaties for life. 
Section IV 。

THE LATER HAMLET AND KING LEAR

To return to Hamlet. That play, first handled by Shakespeare very early in his: dramatic career, appears to have become the receptacle of much of his thought on his art and on life in general. The motif that prob. ably underlay its earliest form, whether Shakespeare's work or another's, has been suggested above; the second quarto and the folio versions give an immensely deeper and wider outlook.

The opening words of the great soliloquy: "To be or not to be, that is the question," seem to imply that in what follows we shall be taught to pluck out the heart of Hamlet' mystery. The speech with this opening line appears in all three extant versions, though the first quarto varies greatly afterwards, and omits "whether 'tis nobler in the mind to suffer or to take arms." They were, however, probably understood. If we turn to the third act (Scene 13 of Boas's edition) of the Spanish Tragedy, we find a soliloquy of Hieronimo's which seems to cast light on the earliest meaning of Hamlet's speech. Hieronimo enters 


\section{HAMLET AND THE GOOD}

with a book in his hand, as Hamlet does in the first quarto, and begins:

$$
\text { "Vindicta mihi }
$$

I, heaven will be revenged of every ill;

Nor will they suffer murder unrepaid.

Then stay, Hieronimo, attend their will:

For mortal men may not appoint their time.

[Here he apparently reads from his Seneca.

'Per scelus semper tutum sceleribus item.'

Strike, and strike home, where wrong is offered thee; For evils unto ills conductors be, And death's the worst of resolution." /)

Now if we assume for the moment in the Hamlet speech that what is "to be or not to be " is vengeance-which is exactly what we suppose on a first reading-we get a nearly parallel process of thought. Both heroes are balancing the question whether it is nobler, more moral to suffer, leaving vengeance to Heaven, or to take arms, strike home against the evil thing, and so put an end at once to the chain of sin. One notes that later on (in the folio version) Hamlet, speaking to Horatio, says: "Is't not perfect conscience to quit him with this arm, and is't not to be damn'd to let this canker of our nature come in further evil"? Hamlet, having put his doubt, goes off, as it appears, at a tangent:

$$
\text { "To die, to sleep }
$$

No more, and by a sleep to say we end 
The heartache, and the thousand natural shocks

That flesh is heir to, 'tis a consummation Devoutly to be wished."

But the connection of the idea of death with what goes before is clear in Hieronimo's case, and was perhaps in the first version of Hamlet. Hieronimo will almost certainly be put to death as a result of his vengeance, and he is trying to reconcile himself to it. "Death's the worst of resolution "- that is, of my being resolved-and there is no certainty that I shall escape even if I refuse to do my duty. In the earliest Hamlet the link was probably the same, but to our Hamlet who has "will and strength and means to do it" there is no obvious connection between his vengeance and his own death. It has been suggested that "to be " should be taken absolutely, and that what Hamlet is discussing is the question of suicide. He is contrasting life and death, and this gives coherence to the speech. Now it seems probable that this is the question of the final Hamlet, and it throws a most interesting light on the line along which Shakespeare's mind has travelled. Hieronimo had balanced the moral question whether the Christian virtue of patience or the pagan of resistance to evil were the finer, but he had no real doubt on the subject. It is simply one of the half-conscious 
excuses he makes to himself for his delay. Hamlet by the time of the second quarto is really occupied with the question, Is the vengeance after all worth while? and later on in the soliloquy suggested by the sight of Fortinbras's army, which appears only in the second quarto, he answers the question: "Rightly to be great is not to stir without great argument, but greatly to find quarrel in a straw when honour's at the stake." This is almost the point of view of the Senecan hero, and so is the thought "it cannot be, but I am pigeonlivered and lack gall to makeoppression bitter." The fear that assailed Atreus is realized in Hamlet-the divine mania has not descended on him, and he feels himself a base creature. And then in the final version there comes the further thought that the mental world is the only reality. "There's nothing either good or bad, but thinking makes it so," and if only our minds are not poisoned we may be "bounded jin a nutshell" and yet be "Kings of infinite space." But something has impaired Hamlet's vision. It is not now whether vengeance is to be or not to be, but whether existence is to be desired.

For Hamlet, as for Orestes, life has lost its savour, and there is nothing wherewith to bring back the glory. "By our own spirits 


\section{0 " HAMLET" AND "KING LEAR"}

are we deified," and if that light goes we realize that we are the prisoners of existence. The completeness of that despair sets us above the trivialities of pain and grief, and so gives the deific calm of tragedy. "The rest is silence." But is there in Hamlet any consolation beyond this?

That is one aspect of the subject of tragedy: King Lear is another. We are no longer concerned with the reality of the glory while it lasts, but recognizing the deity of manhood in its prime, we realize with a mad despair its passing from us. The tyranny of physical decay saps Lear's virility. In the older play there was scarcely a hint of the almost too terrible scene where the proud old man breaks down before the utterly heartless reasoning of his children. "You see me here, you gods, a poor old man, as full of grief as age; wretched in both. ... Let not women's weapons, water-drops, stain my man's cheeks! No, you unnatural hags (becoming impotently furious), I will have such revenges on you that all the world shall-I will do such things,-what they are, yet I know not; but they shall be the terrors of the earth. You think I'll weep (of course he is weeping). No, I'll not weep: I have full cause of weeping; but this heart shall break into a hundred thousand flaws, or ere I'll weep. O fool, I shall go mad !" 
Again, the only comfort of tragedy is its own completeness. This decay is the essence of humanity, which no god can know: in this awful desolation, whatever gods there be are powerless against us, because the worst has happened.

\section{Section V}

CONCLUSION: THE INDIVIDUAL IS ESSENTIALLY TRAGIC: CONSOLATION IS ONLY POSSIBLE WHEN WE REGARD ALL LIFE AS ONE

The solution of the problems of Hamlet and of Lear alike is given in the Reconciliation plays. It was a solution towards which Shakespeare seems to have been working very early. Tragedy is the history of an individual; the Reconcliation plays treat of the story of a group of people, usually a family, and always consisting of two generations. He thinks of the race as one, of decay and death as a wonderful process which links all life together in harmonious interchange of being-" nothing of us that doth fade, but doth suffer a seachange into something rich and strange.". The harmony of the comedies, real with the reality of a future in which perfectly developed human natures shall create a perfect society, is only 
possible against a background of the inanimate world. In the folk-play, with its identification of the life in man and beast and plant, he had found a medium or a half-conscious suggestion for his philosophy. Nature itself comes alive in the Tempest both in the savage romance of its earthiness and in that delicate ethereal element which is the other side of this "grossseeming" world. And in the Tempest the claim of human kinship receives its fullest expression:

" Hast thou, which art but air, a touch, a feeling Of their afflictions, and shall not myself, One of their kind, that relish all as sharply, Passion as they, be kindlier mov'd than thou art ? The rarer action is

In virtue than in vengeance."

For the individual, taken as a unit, life must be tragic: he will decay and die, and the greater his consciousness of personality the more awful the dissolution must be. But if we look on all life as one, decay and death are merely part of the great harmonizing and transmuting process. Hamlet had realized this, and " his gorge rose at it," but to Prospero the thought has a strange beauty. 


\section{From B. H. BLACKWELL'S LIST.}

\section{क}

ARTHUR BOURCHIER.

\section{Some Reflections on the Drama-and}

Shakespeare. A Lecture delivered (at the invitation of the Vice-Chancellor), in the Examination Schools of Oxford University, on Friday, February 3, IgIr. Crown 8vo, sewed, Is. net.

"Mr. Bourchier . . . touches on many topics that are engaging the attention of the world of drama at the present time. Mr. Bourchier argues eloquently and at length in favour of a National Theatre, and believes that Shakespeare should have the most magnificent mounting that the stage can afford."-TheAberdeen Free Press.

\section{\%}

H. C. BEECHING, M.A.

(Dean of Norwich.)

George Herbert's "Country Parson." Edited, with Introduction, by H. C. BEECHING. Reissue, paper cover, with labels, Is. $6 \mathrm{~d}$. net.

"Breathes there a lover of books ... who ... will not wel. come this attractive little volume? The get-up and printing are so good that we regard it as a model reprint."-The Literary World.

C. H. FIRTH.

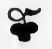

(Regius Professor of History in the University of Oxford.)

An American Garland. Being a Collection of Ballads relating to America, I 563-1759. Edited with Introduction and Notes. 8vo, Roxburgh binding, 3s. $6 \mathrm{~d}$. net.

". . . A collection of exceptional interest, neatly bound and well printed, this is a garland which everybody with the slightest tincture of historic sense will joyfully welcome."-The Guardian.

Oxford: B. H. BLACKWELl, Broad Street. 


\section{From В. H. BLACKWELL'S LIST.}

ARTHUR HASSALL, M.A.

(Student of Christ Church.)

Life of Viscount Bolingbroke. Second

Edition, revised, and in part re-written. Crown 8vo, cloth, 3s. 6d. net.

"The best and most readable introductory account of Bolingbroke in the language." - The Observer.

W. WARDE FOWLER.

(Author of "A Year with the Birds.")

"Everything Mr. Warde Fowler writes is worth reading."-Pall Mall Gazette.

Kingham Old and New. Studies in a Rural Parish. With Frontispiece by E. H. Neiv, Plan of the Parish, and Map. Imp. I6mo, clo:h extra, 5s. net.

"A MODEL."

". . . It will stand, at any rate on one shelf, very near WALDBV, and Cranford and the AUtocrat and Lowell's Fireside Travels." -The Spectator.

"The Kingham observations are in the right succession of Selborne."-The Timos.

"In the beautiful limpidity of his style and the mingling in him of the antiquary and the naturalist he often makes us think of Gilbert White."-The Atheneum.

ROBERT BRIDGES.

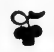

(Poet Laureate.)

The Small Hymn Book. The Word Book of the Yattendon Hymnal. Fcap 8vo, sewerl, $2 \mathrm{~s}$. $6 \mathrm{~d}$. net; for congregational use, $16 \mathrm{mo}, 6 \mathrm{~d}$. net, $\mathrm{cr}$ $£ 2$ net per roo.

"It is no exaggeration-it is the bare, literal truth-to say that it is incomparably the finest collection of hymns that has ever yet been published." - The New Witness.

OXFORD :

B. H. BLACKWELL, BROAD STREET.

New York Agents: Longmans, Green \& Co. 





\section{PLEASE DO NOT REMOVE \\ CARDS OR SLIPS FROM THIS POCKET}

\section{UNIVERSITY OF TORONTO LIBRARY}

PR

2952

S6
Spens, Janet An essay on Shakespeas relation to tradition 


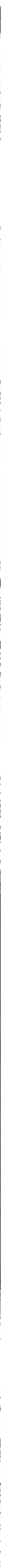

